\title{
Feeding cows with hay, silage, or fresh herbage on pasture or indoors affects sensory properties and chemical composition of milk and cheese
}

\author{
E. Manzocchi, ${ }^{1} \odot$ B. Martin, ${ }^{2 *} \odot$ C. Bord, ${ }^{3} \odot \mathrm{I}$. Verdier-Metz, ${ }^{3} \odot$ M. Bouchon, ${ }^{4} \odot \mathrm{M}$. De Marchi, ${ }^{5} \odot \mathrm{I}$. Constant, $^{2}$ \\ K. Giller, ${ }^{1} \odot$ M. Kreuzer, ${ }^{1} \odot$ J. Berard,,${ }^{6,7} \odot$ M. Musci, ${ }^{8} \odot$ and M. Coppa ${ }^{9} \odot$ \\ ${ }^{1}$ ETH Zurich, Institute of Agricultural Sciences, Universitätstrasse 2, 8092 Zurich, Switzerland \\ ${ }^{2}$ Université Clermont Auvergne, INRAE, VetAgro Sup, UMR 1213 Herbivores, 63122 Saint-Genès-Champanelle, France \\ ${ }^{3}$ Université Clermont Auvergne, INRAE, VetAgro Sup, UMR 545 Fromage, 15000 Aurillac, France \\ ${ }^{4}$ Université Clermont Auvergne, INRAE, Herbipôle, 63122 Saint-Genès-Champanelle, France \\ ${ }^{5}$ Department of Agronomy, Food, Natural Resources, Animals and Environment (DAFNAE), University of Padova, Viale dell'Università 16, \\ 35020 Legnaro (PD), Italy \\ ${ }^{6}$ ETH Zurich, AgroVet Strickhof, Eschikon 27, 8315 Lindau, Switzerland \\ ${ }^{7}$ Agroscope, Division Animal Production Systems and Animal Health, 1725 Posieux, Switzerland \\ ${ }^{8}$ Department of Food and Drug, University of Parma, Parco Area delle Scienze 27/A, 43124 Parma, Italy \\ ${ }^{9}$ Independent researcher at Université Clermont Auvergne, INRAE, VetAgro Sup, UMR 1213 Herbivores, 63122 Saint-Genès-Champanelle, \\ France
}

\section{ABSTRACT}

In European countries, silage-free feeding is an ancient tradition and has a particularly positive reputation among consumers. In the present study, we compared grass-based forages from the same plot conserved as hay or silage or fed fresh either on pasture or indoors, and we evaluated the differences in sensory properties of milk and uncooked pressed cheese. All herbage from the first cut of a grassland dominated by perennial ryegrass was harvested on the same day and preserved either as hay or silage. The first regrowth of the same plot was used for strip grazing or green feeding indoors. Balanced by breed, 24 Montbéliarde and 24 Holstein cows were allocated to the 4 treatments. Apart from the forages, the late-lactation cows received $3 \mathrm{~kg} / \mathrm{d}$ of dry matter from concentrate. After 2 wk of dietary adaptation, the bulk milk of 3 subgroups, each with 4 cows, was collected. Part of the milk was pasteurized, and part was left raw and partly transformed to small-sized Cantal-type cheese ripened for 9 wk. Milk and cheese underwent descriptive sensory analysis by a trained sensory panel, as well as analyses of physicochemical traits. Volatile organic compounds of the cheeses were also analyzed. Raw and pasteurized milk from hay-fed cows had less intense odors of cooked milk, cream, and barnyard than milk from grazing cows, whereby the effect of pasteurization did not differ between herbage utilization methods. Cheeses obtained from cows fed fresh herbage (grazing and indoors) were clearly

Received October 5, 2020.

Accepted November 28, 2020.

*Corresponding author: bruno.martin@inrae.fr yellower than cheeses from silage- and hay-fed cows, which coincided with the color intensity perceived by the panelists. Moreover, cheeses from cows fed fresh herbage had more intense barnyard and dry fruit flavors, were perceived as creamier and having less lactic odor, and exhibited more fat exudation than those from cows fed conserved herbage. Only a few differences were observed in milk and cheeses from hay-fed compared with silage-fed cows, and those differences were far less pronounced than those of milk and cheeses from cows fed fresh herbage. In conclusion, the present study did not substantiate assumptions of clear sensory differences of milk and uncooked pressed cheese from hay-fed compared with silage-fed cows. For the first time, this study reports that the global flavor intensity of cheeses from indoor green-fed cows is similar to that of cheeses derived from cows fed conserved forages, whereas cheeses from grazing cows have the greatest global flavor intensity.

Key words: herbage utilization method, dairy cow, milk sensory profile, cheese sensory profile

\section{INTRODUCTION}

Grassland-based dairy production systems are increasingly emerging as a strong option for future sustainable livestock systems because they valorize resources not competing with human food supply and provide valuable ecosystem services (Dumont et al., 2018). These production systems are also known to deliver products with high added value characterized by specific nutritional and sensory properties that have been intensively investigated in previous decades (see reviews by Martin et al., 2009a; Kilcawley et al., 2018). 
It has been demonstrated that feeding herbage-based diets results in a favorable milk fatty acid (FA) composition and elevated contents of fat-soluble vitamins and antioxidants compared with corn- and concentratebased diets (Butler et al., 2011). Furthermore, volatile organic compounds (VOC) directly originating from the herbage or derived from substrates in the herbage affect the sensory properties of milk and cheese (reviewed by Kilcawley et al., 2018). Accordingly, the herbage utilization method and closely related aspects such as the botanical composition and phenological stage of the herbage were reported to affect the composition and sensory properties of milk and cheese (Coppa et al., 2011a, 2015b) as well as the VOC profile of milk (Coppa et al., 2011b) and cheese (Cornu et al., 2009). In some studies, the sensory perception of raw milk and cheese from hay- or silage-fed cows differed (Dubroeucq et al., 2002; Verdier-Metz et al., 2005). Other authors reported that panelists could not distinguish pasteurized milk from cows fed timothy silage or timothy hay in a triangle test (Villeneuve et al., 2013). Fatty acid profiles of the milk of hay- or silage-fed cows may slightly differ (Ferlay et al., 2006; Halmemies-Beauchet-Filleau et al., 2013), whereas the physicochemical properties of the milk seem to remain unaffected (Manzocchi et al., 2020). Often, producers of artisanal hard and semihard cheese do not use milk from silage-feeding farms to avoid the risk of late swelling and off-flavor issues occurring during cheese ripening if spores of butyric acid bacteria of silage origin are present in milk. However, the effect of herbage conservation per se on the sensory properties of milk and cheese in previous investigations was often confounded with the effect of botanical composition and phenological stage (i.e., the typically later harvest date for haymaking). To the best of our knowledge, only 2 experiments investigated the effect of forage conservation method using herbage harvested simultaneously from the same plot on cheese sensory quality and VOC profile: Saint-Nectaire type cheese from a permanent grassland (Verdier-Metz et al., 1998) and Caciocavallo, a stretched curd cheese, from a temporary subtropical grass (Serrapica et al., 2020). As the diet effects on the sensory properties differ depending on the cheese model (Verdier-Metz et al., 2005), validation by other cheese models is needed and the direct link of compositional changes to the sensory properties of milk and uncooked pressed cheese and their VOC profile has to be demonstrated.

As an alternative to herbage conservation and grazing, indoor green-feeding is an established practice in grassland-based dairy production systems during the growing season (Akert et al., 2020). Feeding selection behavior may differ between grazing cows and indoor green-fed cows (Boudon et al., 2006). In the latter, the proportions of rumenic acid (cis-9,trans-11-C18:2) and vaccenic acid (trans-11-C18:1) in milk were found to be lower than in grazing cows offered the same herbage (Leiber et al., 2005; Mohammed et al., 2009). This difference and possible other dietary differences may affect the sensory characteristics of milk and cheese through changes in the microbial or endogenous formation of VOC in rumen, milk, or cheese (Coppa et al., 2011b, 2015a; Giaccone et al., 2016). To our knowledge, no comparisons of the 4 herbage utilization methods regarding their effects on the sensory properties of milk and the VOC profile of cheese have been reported in the literature. Therefore, we tested the following hypotheses: (1) the composition of milk and cheese as well as the VOC profile of the cheese produced from cows fed hay, silage, and fresh herbage on pasture or indoors differ even when the forages are harvested from the same plot; and (2) this variation leads to different sensory properties of raw or pasteurized milk and uncooked pressed cheeses.

\section{MATERIALS AND METHODS}

\section{Diets and Animals}

The experiment was conducted at the experimental facility of INRAE Herbipôle in Marcenat $\left(45^{\circ} 15^{\prime} \mathrm{N}\right.$, $2^{\circ} 55^{\prime} \mathrm{E}$; 1,135-1,215 m above sea level, Cantal, France; https://doi.org/10.15454/1.5572318050509348E12). The local ethics committee approved the experimental protocol (approval number 20190425141273). In July 2019, 24 Montbéliarde and 24 Holstein cows (8 primiparous and 16 multiparous of each breed) were randomly allocated to 4 groups balanced for breed, parity, and milk yield. At the beginning of the experiment, the cows were $251 \pm 25$ DIM (mean \pm SD) and their milk production was $15.1 \pm 3.3 \mathrm{~kg} / \mathrm{d}$. The average milk fat and protein contents were $3.8 \pm 0.4 \%$ and 3.3 $\pm 0.3 \%$, respectively. Three experimental groups were housed in a freestall barn. The first group was fed hay ad libitum. The second group was fed grass silage ad libitum and $2 \mathrm{~kg}$ of DM/d of the same hay as fed to the first group. The third group was fed indoors with green herbage harvested daily and offered an amount estimated to result in a surplus of about $5 \%$ of the voluntary intake. The fourth group strip grazed on a portion of the same plot during the whole day, except during milking. All animals were supplemented with $3.0 \mathrm{~kg}$ of $\mathrm{DM} / \mathrm{d}$ of a commercial concentrate (on a DM basis: $17.2 \%$ corn, $14 \%$ wheat, $14 \%$ barley, $14 \%$ wheat bran, $14 \%$ sunflower cake, $11.9 \%$ rapeseed meal, $5 \%$ cereal grains, $2 \%$ molasses, and $7.9 \%$ mineral-vitamin premix) and had free access to mineral licking blocks (SODI SoMag, Salins). Water was constantly available 
to all experimental groups. All cows were milked at 0630 and $1600 \mathrm{~h}$ in a herringbone milking parlor.

\section{Plot Characteristics and Forages}

A 6-ha intensively managed grassland plot dominated by ryegrass and timothy was harvested on May 15, 2019 (first cut), at the early heading stage to produce the experimental hay and grass silage. The botanical composition of the sward was surveyed according to the point-quadrat method (Daget and Poissonet, 1969) directly before harvest and $7 \mathrm{wk}$ later at the beginning of the experiment (i.e., the feeding of fresh herbage for $24 \mathrm{~d}$ ), respectively. Concomitantly, the phenological stage of grasses was determined using the scale of the Biologisches Bundesanstalt Bundessortenamt und Chemische Industrie (BBCH; Hack et al., 1992). The average $\mathrm{BBCH}$ stage was 53 at harvest of hay and silage and 47 at the beginning of the experiment. Table 1 reports the most abundant species and the proportions of grasses, legumes, and nonlegume forbs for both dates. Herbage for silage was directly harvested, chopped, and stored in a plastic bag silo. Herbage for haymaking was wilted for $72 \mathrm{~h}$, raked, baled, and barn-dried. Fresh herbage for green feeding indoors was harvested with a cutting and loading truck. Grazing cows were offered a new strip biweekly. Stocking density was 4 cows/ha and herbage biomass on the sward $5 \mathrm{~cm}$ above ground was $2.7 \mathrm{t}$ of DM/ha. Fresh herbage from pasture and offered indoors was sampled weekly. One aliquot was dried $\left(60^{\circ} \mathrm{C}, 72 \mathrm{~h}\right)$, whereas another aliquot was preserved at $-20^{\circ} \mathrm{C}$. In addition, simulated bites of the grazing cows were sampled according to Coppa et al. (2015a) on d 17 of the experiment and frozen at $-20^{\circ} \mathrm{C}$.

\section{Milk Sampling and Cheesemaking}

For bulk milk sampling and cheesemaking, the 4 groups of 12 cows each were further divided into 3 balanced subgroups of 4 cows each, to obtain 3 independent replicates of bulk milk per herbage utilization method. Each subgroup was balanced for breed, milk yield, and fat and protein content. On d 16, 23, and 24 of the experimental period, evening bulk milk of 1 subgroup per diet was collected and stored at $4^{\circ} \mathrm{C}$ until the next morning. At the morning milking, bulk milks of the same subgroups were collected and blended with the respective evening milk. At first, two 3-L samples of bulk milk per subgroup were either stored in glass bottles at $4^{\circ} \mathrm{C}$ or pasteurized $\left(75^{\circ} \mathrm{C}, 3 \mathrm{~min}\right)$ and stored at $4^{\circ} \mathrm{C}$. Sensory evaluation of raw milk was performed on the same day of every cheesemaking event, and that of pasteurized milk on the day after (within 28 $\mathrm{h}$ from pasteurization). Thirty liters of raw bulk milk per subgroup was simultaneously processed to cheese in 1 of 4 vats. Considering the 3 sampling dates, this yielded 12 vats (3 per herbage utilization method) and 72 cheeses (6 per vat) weighing approximately $500 \mathrm{~g}$. The cheese model applied was Cantal-type cheese, an uncooked, grounded, and pressed cheese, produced with nonstandardized milk. The Cantal-type cheeses were produced as described by Martin et al. (2009b), but the method was adapted to obtain small-sized cheeses. The raw milk was heated to $33^{\circ} \mathrm{C}$ and then inoculated with $0.015 \mathrm{~g}$ of lyophilized mesophilic starter culture (Flora Danica Direct, Chr. Hansen) reconstituted in sterile skim milk $(1 \mathrm{~g} / \mathrm{L})$, ripening starters $(0.32 \mathrm{~mL}$ of Monilev and $0.16 \mathrm{~mL}$ of Penbac, Laboratoire Interprofessionnel de Production), and $9 \mathrm{~mL}$ of rennet (Fabre 520, LCP Food Ingredients) containing active chymosin at $520 \mathrm{mg} / \mathrm{L}$. The curd was cut $45 \mathrm{~min}$ later for 1.5 min to reach corn kernel sizes of 5 to $6 \mathrm{~mm}$, blended for $12 \mathrm{~min}$, and left to rest for $5 \mathrm{~min}$. After the whey was drained, the curd was pressed into a tray, cut into 5 -cm cubes, and turned every $15 \mathrm{~min}$ for $90 \mathrm{~min}$. After pressing, the curd was left to drain for $24 \mathrm{~h}$ at $24.5^{\circ} \mathrm{C}$,

Table 1. The 10 most abundant plant species of first cut (hay and silage) and first regrowth (herbage fed on pasture and indoor) of the plot where experimental forages were produced

\begin{tabular}{lcc}
\hline Species & SC, ${ }^{1} \%$ & $\mathrm{SE}$ \\
\hline Conserved forages & & \\
Lolium perenne & 19.1 & 2.76 \\
Phleum pratense & 14.4 & 8.30 \\
Taraxacum officinale & 13.9 & 3.64 \\
Trifolium repens & 13.2 & 4.52 \\
Bromus hordeaceus & 11.9 & 7.78 \\
Poa pratensis & 7.4 & 3.19 \\
Dactylis glomerata & 5.7 & 2.23 \\
Festuca pratensis & 3.1 & 1.88 \\
Veronica chamaedrys & 2.1 & 0.77 \\
Lamium album & 1.8 & 0.94 \\
Functional groups & & \\
Grasses & 64.6 & 7.25 \\
Legumes & 13.8 & 4.12 \\
Nonlegume forbs & 21.6 & 4.74 \\
Fresh herbage & & \\
Lolium perenne & 19.9 & 9.96 \\
Poa pratensis & 19.3 & 3.64 \\
Taraxacum officinale & 9.09 & 7.10 \\
Agrostis tenuis & 8.79 & 4.40 \\
Lolium multiflorum & 7.62 & 5.70 \\
Festuca pratensis & 7.25 & 2.82 \\
Trifolium repens & 7.09 & 7.01 \\
Dactylis glomerata & 5.84 & 1.80 \\
Ranunculus bulbosus & 5.09 & 3.09 \\
Phleum pratense & 3.44 & 3.83 \\
Functional groups & & \\
Grasses & 76.8 & 10.19 \\
Legumes & 7.1 & 7.01 \\
Nonlegume forbs & 16.1 & 6.09 \\
\hline SC specific & &
\end{tabular}

${ }^{1} \mathrm{SC}=$ specific contribution. 
pounded to $20-\mathrm{mm}$ grains and salted $(2 \mathrm{~g}$ of $\mathrm{NaCl} / 100$ $\mathrm{g}$ of curd), and rested for $6 \mathrm{~h}$ at $18^{\circ} \mathrm{C}(90 \%$ relative humidity). Then it was put into 6 molds $(90 \mathrm{~mm}$ in diameter) per vat. The cheeses were ripened for $9 \mathrm{wk}$ at $10^{\circ} \mathrm{C}$ and $\geq 97 \%$ relative humidity, and turned twice a week. Milk samples for analysis of gross composition, FA, and total microbial counts were collected from the vats before inoculation with rennet and starter culture.

\section{Laboratory Analyses}

Feeds. Oven-dried forage samples were ground and analyzed for proximate nutrient composition according to Coppa et al. (2015a). Frozen forage samples were lyophilized and ground, and their FA profiles were analyzed by GC according to Ferlay et al. (2010). Samples of fresh grass and simulated bites were sorted by hand into grasses, legumes, and nonlegume forbs and then dried $\left(60^{\circ} \mathrm{C}, 72 \mathrm{~h}\right)$ and weighed to calculate their relative proportion of total DM.

Milk. Milk samples were preserved with bronopol at $4^{\circ} \mathrm{C}$ and analyzed for fat, protein, $\mathrm{CN}$, lactose, urea, and free FA by infrared spectroscopy (MilkoScan, Foss). Somatic cells were counted by flow cytometry (Fossomatic, Foss). Contents of $\mathrm{Ca}, \mathrm{P}, \mathrm{Mg}, \mathrm{K}$, and Na were determined by mid-infrared spectroscopy according to Visentin et al. (2016). Total bacterial counts were analyzed with BactoScan (Foss). Milk color was measured by spectrometry, and $\mathrm{L}^{*}$ (light-dark index), a* (redgreen index), and $\mathrm{b}^{*}$ (yellow-blue index) were quantified according to the CIE (International Commission on Illumination) system. Three milliliters of milk was stored without preservative at $-20^{\circ} \mathrm{C}$ until lyophilization for FA analysis by GC according to Lerch et al. (2015). Additional samples of $50 \mathrm{~mL}$ were stored at $-20^{\circ} \mathrm{C}$ and later analyzed for milk coagulation properties using a Formagraph (Foss) according to the method validated by Penasa et al. (2015). Rennet coagulation time, curd firming time at $20 \mathrm{~mm}$ of curd size, and curd firmness after $30 \mathrm{~min}$ were recorded. Other technological traits (native milk $\mathrm{pH}, \mathrm{pH}$ of pressed and pounded curd, DM content of molded curd) were recorded during every cheesemaking event according to Martin et al. (2009b).

Cheese. After ripening, cheese yield was calculated based on the sum of the weight of all cheeses from 1 vat divided by the initial milk weight. One cheese per vat was used for sensory analysis; another was used for the measurement of rheology, color, chemical composition, and VOC; and the other cheeses were preserved for further analysis. Rheological measurements were repeated 5 times per cheese by uniaxial compression at constant displacement rate as described by Martin et al. (2009b). Strengths exerted by the samples at 20, 40, and $60 \%$ sample deformation under compression were recorded, as well as the Young's modulus. The Young's modulus is the relation of stress to strain during compression and expresses the stiffness of the sample. On the same sample, 5 repeated color measurements were done by spectrometry as detailed for milk. Replicates of rheological and color measurements performed were averaged per cheese. The remainder was frozen at $-20^{\circ} \mathrm{C}$ until further analysis. After samples were thawed overnight at $4^{\circ} \mathrm{C}, \mathrm{DM}$ content was determined according to the reference method (ISO 5534; ISO, 2004b). Chlorides (expressed as $\mathrm{NaCl}$ ) were measured with a potentiometric method (ISO 5943; ISO, 2006). Fat was analyzed with an acid-butyrometric method (AFNOR NF V 04-287 Heiss method; AFNOR, 2002). Lipolysis, expressed as free FA (oleic acid, \% of fat), was measured by titration (ISO 1740; ISO, 2004a). Total nitrogen (TN) was determined by the Kjeldahl method (ISO 8968-1; ISO, 2014). Water-soluble N and phosphotungstic acid-soluble N (PTSN) were analyzed according to Ardö (1999). The volatile fraction of the cheeses was extracted by headspace-solid phase microextraction. Before the extraction, cheese samples were thawed, cut into small pieces, frozen under liquid nitrogen, ground in a domestic blender, and stored at $-20^{\circ} \mathrm{C}$ in screw-cap glass vials until analysis. Four grams of ground cheese was put into a $20-\mathrm{mL}$ hermetic glass vial. The headspace-solid phase microextraction was carried out by exposing a $50 / 30-\mu \mathrm{m}$ divinylbenzene-carboxenpolydimethylsiloxane fiber (Supelco) for $40 \mathrm{~min}$ to the headspace of the vial thermostatically controlled at $50^{\circ} \mathrm{C}$. The fiber was then removed from the vial and inserted for 10 min into a GC-MS injector, maintained at $230^{\circ} \mathrm{C}$, to desorb the extracted compounds. Injections were performed in splitless mode, keeping the valve closed for $3 \mathrm{~min}$. The compounds were separated by GC-MS, performed on a Trace 1300 gas chromatograph coupled to an ISQ single quadrupole mass spectrometer (both Thermo Fisher) equipped with an electronic impact source. The VOC separation was performed on a SupelcoWax 10 capillary column (Supelco, $30 \mathrm{~m} \times 0.25$ $\left.\mathrm{mm}, \mathrm{d}_{\mathrm{f}} 0.25 \mu \mathrm{m}\right)$. Helium was used as the carrier gas with a total flow of $1 \mathrm{~mL} / \mathrm{min}$. The oven temperature program was as follows: isothermal at $50^{\circ} \mathrm{C}$ for $5 \mathrm{~min}$; increase at $10^{\circ} \mathrm{C} / \mathrm{min}$ until $100^{\circ} \mathrm{C}$; increase at $20^{\circ} \mathrm{C} / \mathrm{min}$ until $220^{\circ} \mathrm{C}$; and isothermal at $220^{\circ} \mathrm{C}$ for $10 \mathrm{~min}$. The transfer line temperature was $230^{\circ} \mathrm{C}$. Mass spectral data were acquired in full scan mode in the mass range 35 to $350 \mathrm{amu}$ (scan time $0.2 \mathrm{~s}$ ). Signal acquisition and data processing were performed using the software Xcalibur (Thermo Scientific). Qualitative analysis was performed by comparing the obtained spectra with those stored in the National Institute of Standards and Technology. In 
addition, Kovats retention indices $(\mathbf{K I})$ were calculated for each chromatographic peak and compared with literature data (Bianchi et al., 2007). Where possible, the retention time of the chromatographic peak was compared with that of authentic standards injected under same chromatographic conditions. A semiquantitative analysis was performed by integrating chromatographic peak areas. Values of 3 analytical replicates per cheese sample were averaged. For statistical analysis, chromatographic peak areas of the compounds were transformed to $\log _{10}\left(\right.$ peak area $\left.\times 10^{-5}\right)$.

\section{Sensory Evaluation of Milk and Cheese}

Milk. Nine trained panelists performed a descriptive sensory analysis of the $2 \times 12$ raw and pasteurized milk samples according to 19 attributes: 2 for appearance, 5 for odor, 6 for taste, 5 for flavor, and 1 for texture (Supplemental Table S1, https://doi.org/10 .15454 /WZWS4P). The panelists had more than $20 \mathrm{~h}$ of experience in evaluating dairy products and were trained in the generation of attributes and use of the perception scales according to ISO 8586-1 standard norms (ISO, 2012). During 5 training sessions of 1.5 $\mathrm{h}$ each, 5 commercial milks and raw milk were used to generate the sensory attributes and to set references on the intensity scale of each attribute. The performance of the panel was evaluated with different discrimination (paired-comparison and triangle tests) and descriptive tests during the last 2 training session. During the evaluation sessions, the intensity of perception of each attribute was scored on a continuous scale from 0 (no perception) to 10 (very intense perception). In each evaluation session, 4 samples labeled with 3-digit codes were served in a sequential monadic way and randomized order in clear plastic glasses. The milk was served at $20 \pm 2^{\circ} \mathrm{C}$. Between every sample, panelists rinsed their mouth with water and unsalted crackers. Data were collected with the Tastel software (version 2019, ABT Informatique).

Cheese. Ten trained panelists assessed the 12 ripened Cantal-type cheeses in 3 sessions ( 1 session per cheesemaking event). The panelists had participated in $6 \mathrm{~h}$ of specific training on Cantal-type cheeses, in addition to the routine training procedure on dairy products according to ISO 8586-1 standard norms (ISO, 2012). Twenty-five attributes were applied to assess the sensory properties of the cheeses: 4 for appearance, 7 for odor, 3 for taste, 7 for flavor, and 4 for texture (Supplemental Table S2, https://doi.org/10.15454/ WZWS4P). Triangular pieces of cheese $(30 \mathrm{~g})$ with the rind on 1 side were served at $21 \pm 2^{\circ} \mathrm{C}$ on white plastic dishes using a monadic sequential method and in a randomized order. After evaluation of the appearance and intensity of odor with the rind, the panelists were asked to remove the rind and continue the evaluation of odor (without the rind), taste, flavor, and texture. The intensity of perception of each attribute was graded according to the same continuous scale used for milk samples and recorded with the same software.

\section{Statistical Analyses}

Data on milk yield, composition, cheese properties, cheese VOC, and cheesemaking traits were analyzed by ANOVA with the GLM procedure in SAS (version 9.4, SAS Institute Inc.). The model included herbage utilization method (4 levels) as fixed effect and replicate (cheesemaking event, 3 levels) as random effect. The model for milk sensory data included herbage utilization method (fixed; 4 levels), pasteurization (fixed; 2 levels), panelist (random; 9 levels), and all 2- and 3 -way interactions. For cheese sensory data, the model included the effect of herbage utilization method (fixed; 4 levels), panelist (random; 10 levels), session (fixed; 3 levels), and all 2-way interactions. The 3 -way interaction was omitted because it was never significant. Normality and homoscedasticity of the residuals were tested with the Shapiro-Wilk test and by visual inspection of skewness and kurtosis. No transformations were needed. The Fisher's least significant difference test was applied for multiple comparisons among means of herbage utilization methods. Data are reported as least squares means and standard error of the mean. Differences were considered significant at $P<0.05$, and tendencies were identified when $0.05<P<0.10$. Pearson correlation coefficients $(\boldsymbol{\rho})$ were calculated with the CORR procedure of SAS for variables describing or influencing cheese color, texture, odor, and flavor attributes.

\section{RESULTS}

\section{Forage Characteristics}

Forage proximate composition for the conserved and fresh forages was quite similar (Table 2). The total content of FA and the proportion of C18:3n-3 ( $\alpha$-linolenic acid, ALA) in total FA was numerically lower in hay than in all other forages. The proportion of C16:0 in total FA was numerically higher in hay compared with all other forages. The ratio of C18:2n-6 to C18:3n-3 was numerically higher in hay and silage compared with fresh herbage. Cows on pasture selected on average 71.1 $\pm 2.92 \%$ (mean $\pm \mathrm{SE}$ ) grasses, $18.9 \pm 2.49 \%$ legumes, and $9.9 \pm 1.63 \%$ nonlegume forbs. The corresponding 
Table 2. Composition (mean $\pm \mathrm{SE}$ ) of the conserved and fresh grass-based forages, simulated bites, and the concentrate feed fed during the experiment

\begin{tabular}{|c|c|c|c|c|c|c|}
\hline \multirow[b]{2}{*}{ Item $^{1}$} & \multirow[b]{2}{*}{ Hay } & \multirow[b]{2}{*}{ Silage } & \multicolumn{3}{|c|}{ Fresh herbage } & \multirow[b]{2}{*}{ Concentrate } \\
\hline & & & $\begin{array}{l}\text { Pasture } \\
\text { (offered) }\end{array}$ & $\begin{array}{l}\text { Simulated } \\
\text { bites }\end{array}$ & Indoor & \\
\hline $\mathrm{CP}, \%$ of $\mathrm{DM}$ & $13.1 \pm 0.11$ & $14.6 \pm 0.09$ & $12.5 \pm 0.61$ & $16.1 \pm 0.34$ & $12.3 \pm 0.35$ & $17.9 \pm 0.11$ \\
\hline $\mathrm{NDF}, \%$ of DM & $52.7 \pm 0.11$ & $56.3 \pm 0.60$ & $55.8 \pm 1.17$ & $53.2 \pm 0.64$ & $54.8 \pm 1.49$ & $18.6 \pm 1.43$ \\
\hline $\mathrm{ADF}, \%$ of $\mathrm{DM}$ & $28.2 \pm 0.34$ & $35.0 \pm 0.23$ & $28.7 \pm 0.73$ & $26.5 \pm 0.24$ & $29.1 \pm 0.91$ & $6.8 \pm 0.70$ \\
\hline C16:0 & $22.8 \pm 0.35$ & $15.9 \pm 0.29$ & $16.7 \pm 0.74$ & $15.7 \pm 0.27$ & $17.6 \pm 0.50$ & $23.7 \pm 0.10$ \\
\hline C18:0 & $1.69 \pm 0.01$ & $1.51 \pm 0.01$ & $1.62 \pm 0.19$ & $1.85 \pm 0.12$ & $1.95 \pm 0.08$ & $2.97 \pm 0.03$ \\
\hline cis-9-C18:1 & $2.51 \pm 0.02$ & $3.83 \pm 0.41$ & $2.72 \pm 0.20$ & $2.17 \pm 0.18$ & $3.38 \pm 0.18$ & $37.6 \pm 0.03$ \\
\hline C18:2n-6 (LA) & $15.2 \pm 0.43$ & $19.7 \pm 0.51$ & $13.8 \pm 0.18$ & $15.5 \pm 0.67$ & $14.6 \pm 0.20$ & $26.0 \pm 0.24$ \\
\hline C18:3n-3 (ALA) & $34.5 \pm 0.72$ & $40.6 \pm 0.75$ & $42.6 \pm 1.62$ & $45.1 \pm 1.13$ & $40.3 \pm 1.02$ & $2.21 \pm 0.02$ \\
\hline $\mathrm{C} 18: 2 \mathrm{n}-6 / \mathrm{C} 18: 3 \mathrm{n}-3$ & $0.44 \pm 0.02$ & $0.50 \pm 0.02$ & $0.32 \pm 0.02$ & $0.35 \pm 0.03$ & $0.39 \pm 0.01$ & $11.8 \pm 0.02$ \\
\hline
\end{tabular}

${ }^{1} \mathrm{FA}=$ fatty acids; $\mathrm{LA}=$ linoleic acid $; \mathrm{ALA}=\alpha$-linolenic acid.

values for the herbage offered to indoor green-fed cows were $69.5 \pm 7.94 \%, 12.9 \pm 3.55 \%$, and $17.6 \pm 4.38 \%$, respectively.

\section{Bulk Milk Characteristics}

The milk from hay-fed cows had higher protein and CN contents, whereas fat and lactose contents were similar in all groups (Table 3 ). Total solids were higher in milk from hay-fed cows $(+0.96 \mathrm{~g} / 100 \mathrm{~g}$ milk) and grazing cows $(+0.36 \mathrm{~g} / 100 \mathrm{~g}$ milk) compared with cows fed silage and herbage indoors. The proportion of free FA in milk fat and the counts of somatic cells and total bacteria did not differ between diets. Compared with feeding conserved forages, fresh grass increased the proportions of PUFA in milk $(+0.94 \mathrm{~g} / 100 \mathrm{~g}$ of FA; $P<0.05)$, especially rumenic acid $(+0.56 \mathrm{~g} / 100 \mathrm{~g}$ of FA; $P<0.05)$, and total trans MUFA, in particular vaccenic acid $(+0.85 \mathrm{~g} / 100 \mathrm{~g}$ of $\mathrm{FA} ; P<0.05)$. The proportion of long-chain n-3 PUFA was higher $(+0.23$ $\mathrm{g} / 100 \mathrm{~g}$ of $\mathrm{FA} ; P<0.05)$ in milk from indoor greenfed cows compared with milk from silage-fed cows, and long-chain n-6 PUFA were more abundant $(P<0.05)$ in milk fat from hay-fed cows compared with milk from cows fed the other forages. The SFA proportion was lower in milk from cows fed fresh herbage $(-3.76 \mathrm{~g} / 100$ of FA; $P<0.05)$ than from those fed conserved forages. The sum of even medium-chain FA (C8:0 to C14:0) was higher in milk from hay-fed cows $(+2.54 \mathrm{~g} / 100 \mathrm{~g}$ of FA; $P<0.05)$ compared with milk of all other groups. Milk from silage-fed cows had a lower proportion of odd- and branched-chain FA $(-0.26 \mathrm{~g} / 100 \mathrm{~g}$ of FA; $P<0.05)$ compared with milk of the other groups. Milk color and native $\mathrm{pH}$ did not differ between the dietary treatments. Milk from fresh herbage-fed cows had a higher $\mathrm{Mg}$ concentration $(P<0.05)$ than milk from hay- or silage-fed cows $(+17.5$ and $+22.5 \mathrm{mg} / \mathrm{L}$, respectively), whereas milk from hay-fed cows had a higher $\mathrm{P}$ concentration $(+0.1 \mathrm{~g} / \mathrm{L} ; P<0.05)$ compared with all other groups.

\section{Cheesemaking Properties and Cheese Yield and Composition}

Milk coagulation traits (coagulation time, curd firming time, and curd firmness) did not differ between treatments (Table 4). Pressed curds obtained from milk from grazing cows had a slightly lower $\mathrm{pH}$ compared with all other curds, but $\mathrm{pH}$ of pounded curds and DM content of molded curds did not differ between dietary treatments. The yield of ripened cheese was higher $(P$ $<0.05)$ for hay-fed cows $(+128 \mathrm{~g} / 100 \mathrm{~kg}$ of milk) and grazing cows $(+117 \mathrm{~g} / 100 \mathrm{~kg}$ of milk) than for cows fed silage or fresh herbage indoors. Cheeses did not differ in $\mathrm{pH}, \mathrm{DM}$, fat, salt, and free FA contents. Cheese cores from the groups fed fresh herbage had higher $a^{*}$ $(+1.4 ; P<0.05)$ and $\mathrm{b}^{*}(+3.6 ; P<0.05)$ values than cheeses from cows fed hay or silage. Cheeses from the indoor herbage-fed group were less bright $\left(\mathrm{L}^{*}:-4.0 ; P\right.$ $<0.05)$ than all other cheeses. Total $\mathrm{N}$ content as well as ratios of water-soluble $\mathrm{N}$ and PTSN to TN in cheeses did not differ between the 4 treatment groups. Young's modulus and strength at all degrees of deformation of the cheeses were also similar among treatments.

\section{VOC Profile of the Cheeses}

In total, $47 \mathrm{VOC}$ were detected in the cheeses, which belonged to following chemical classes: 15 alcohols, 12 esters, 6 ketones, 2 hydrocarbons, 3 acids, 3 aldehydes, 2 lactones, 2 sulfurous compounds, and 2 nitrogenous compounds (Table 5). The main compounds desorbing 
Table 3. Effect of herbage utilization method on yield, composition, and color of the milk in the vat before addition of the starter

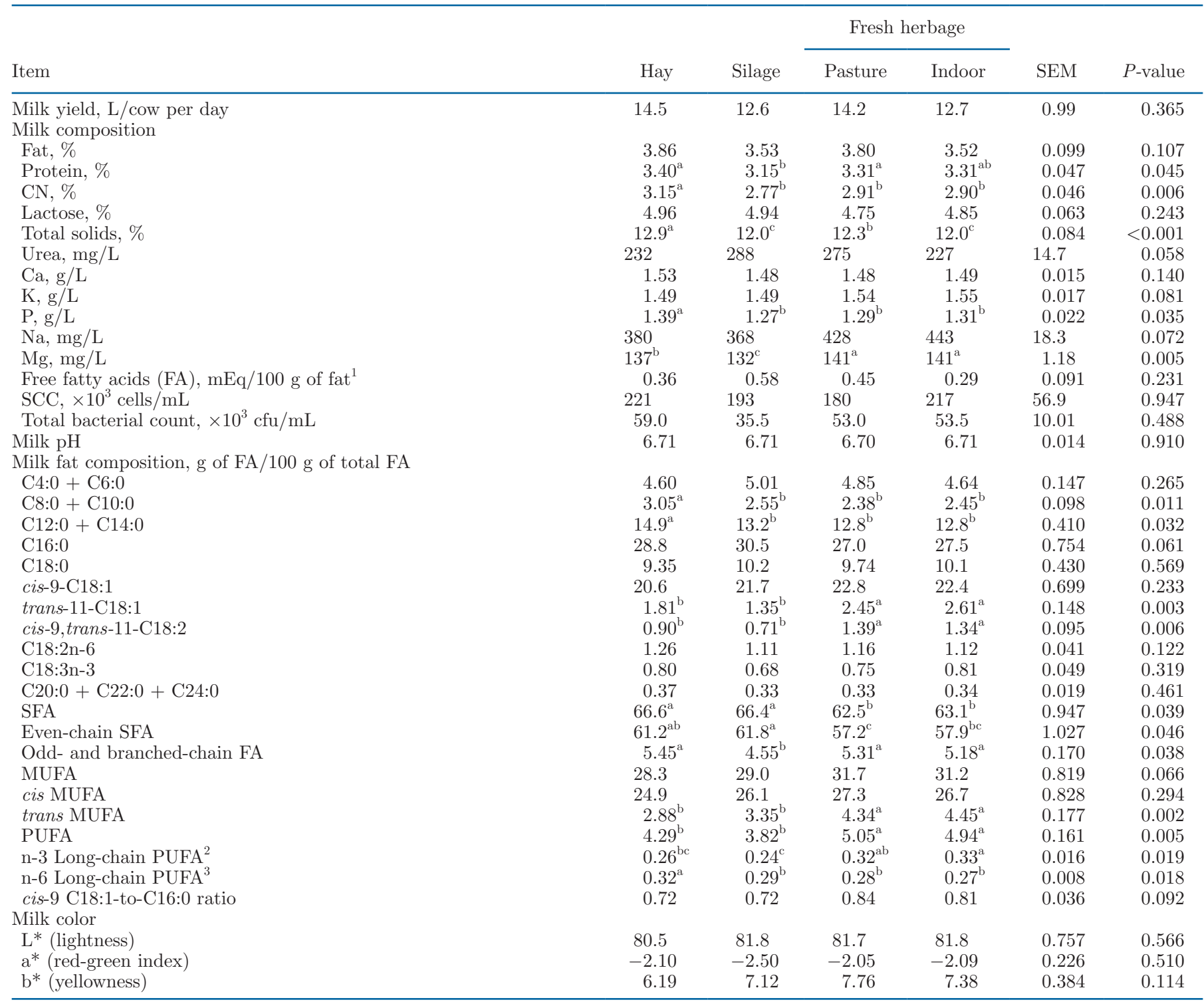

$\overline{\mathrm{a}}^{-\mathrm{c}}$ Means $(\mathrm{n}=3)$ within a row with differing superscripts differ $(P<0.05)$ according to Fisher's least squares difference test.

${ }^{1} 1 \mathrm{mEq}=0.28 \mathrm{~g}$ of oleic acid.

${ }^{2}$ Include C20:5n-3, C22:3n3, C22:5n3, C22:6n-3.

${ }^{3}$ Include C20:2n-6, C20:3n-6, C20:4n-6, C22:2n-6, C22:4n-6.

from the cheeses were hexanoate, butanoate, methyl oleate, methyl stearate, and methyl isohexadecanoate. The concentrations of 8 compounds and 1 compound class were affected by the herbage utilization method. The cheeses from the grazing group had a higher concentration of ethyl butanoate $(+36 \% ; P<0.05)$ than all other cheeses. The concentration of a not identified (NI) compound (KI 1661), putatively a branched ester, was also higher in cheeses from grazing cows $(+31 \%$; $P<0.05)$ compared with cheeses from hay- and indoor green-fed cows. Moreover, the concentration of NI
(KI 1612), putatively 2,4-dimethylpyrrole, was higher $(+17 \% ; P<0.05)$ in cheeses from grazing and silagefed cows than in cheeses from indoor green-fed cows. Cheeses from silage-fed cows had a higher concentration of total lactones and octane than all other cheeses, as well as a higher concentration of 2-phenylethanol $(+39 \% ; P<0.05)$ and 3-methyl-1-butanol $(+43 \% ; P<$ 0.05) compared with cheeses from hay-fed and grazing cows. Furthermore, cheeses from hay-fed cows had a lower concentration of 3-methylbutanal $(-38 \%$; $P<$ $0.05)$ than all other cheeses. In addition, the concentra- 
tions of 2,3-butanediol $(P=0.052)$ and 2-butanone $(P$ $=0.081$ ) were numerically lower in cheeses from hayfed cows than in cheeses from cows fed fresh herbage, either on pasture or indoors. Cheeses from both groups fed conserved forages had a higher concentration of 2-pentanol $(+36 \% ; P<0.05)$ than cheeses from both groups fed fresh herbage.

\section{Sensory Perception of Milk and Cheese}

Milk. The results of the sensory evaluation of the milk are combined for raw and pasteurized milk in Table 6 because no significant interaction of herbage utilization method and pasteurization was observed. Results are presented individually in Supplemental Table S3 (https://doi.org/10.15454/WZWS4P). Pasteurization reduced the yellowness $(P=0.001)$ and increased $(P<0.05)$ the intensity of the cream odor and the barnyard and cooked milk odors and flavors, as well as of the global odor and flavor intensity (Table 6 and Supplemental Table S3). Milks from grazing and indoor green-fed cows had a more intense color $(+1.7$ and +1.2 , respectively; $P<0.001$ ) compared with milk from silage-fed cows, and the color was even more intense $(+2.6$ and +2.1 , respectively) when hay was fed. Milk from the latter group had a lower global odor intensity $(-0.8 ; P<0.05)$ than milk from cows of both groups fed fresh herbage. The odor attributes cooked milk $(P<0.05)$, cream $(P<0.05)$, and barnyard $(P<$ $0.05)$ were perceived as less intensive $(-0.8,-0.8$, and -0.7 , respectively) in milk from hay-fed cows than in milk from grazing cows. Milk from hay-fed cows differed from that of silage-fed cows only by a lower intensity of cream odor $(-0.6)$.

Cheese. Grazing and indoor green-feeding clearly increased the yellowness of the cheese core (Table 7). Cheeses from hay-fed cows were perceived to be the lightest $(P<0.001)$ and presented a more uniform coloring of the paste $(P<0.01)$ than all other cheeses. Grazing, but not indoor green-feeding, resulted in cheeses with a stronger global flavor $(+0.6 ; P<0.05)$ than all other cheeses. The barnyard flavor was more

Table 4. Effect of herbage utilization method on processing traits, cheese yield, chemical composition, color, and rheology of Cantal-type cheese $(\mathrm{n}=3$ per diet) after 9 wk of ripening

\begin{tabular}{|c|c|c|c|c|c|c|}
\hline Item & Hay & Silage & \multicolumn{2}{|c|}{ Fresh herbage } & SEM & $P$-value \\
\hline Curd firming time, min & 5.3 & 3.0 & 6.0 & 5.6 & 1.20 & 0.373 \\
\hline Curd firmness, mm & 29.9 & 28.4 & 32.2 & 33.5 & 4.91 & 0.887 \\
\hline pH pressed curd & $6.66^{\mathrm{a}}$ & $6.67^{\mathrm{a}}$ & $6.63^{\mathrm{b}}$ & $6.67^{\mathrm{a}}$ & 0.006 & 0.015 \\
\hline Cheese yield, $\%$ & $10.7^{\mathrm{a}}$ & $9.4^{\mathrm{b}}$ & $10.1^{\mathrm{ab}}$ & $9.5^{\mathrm{b}}$ & 0.249 & 0.037 \\
\hline \multicolumn{7}{|l|}{ Cheese composition } \\
\hline DM, \% & 65.8 & 65.2 & 64.6 & 66.6 & 0.768 & 0.368 \\
\hline Fat, \% & 34.5 & 34.0 & 34.0 & 34.1 & 0.539 & 0.896 \\
\hline Fat in DM, \% & 52.4 & 52.1 & 52.7 & 51.2 & 0.561 & 0.378 \\
\hline Chlorides $(\mathrm{NaCl}), \%$ & 1.87 & 1.92 & 1.87 & 1.77 & 0.065 & 0.480 \\
\hline Chlorides in DM $(\mathrm{NaCl}), \%$ & 2.84 & 2.95 & 2.89 & 2.65 & 0.131 & 0.476 \\
\hline $\mathrm{PTSN} / \mathrm{TN}$ & 4.67 & 4.35 & 4.99 & 5.12 & 0.294 & 0.338 \\
\hline \multicolumn{7}{|l|}{ Color of cheese core } \\
\hline $\mathrm{L}^{*}$ (lightness) & $80.1^{\mathrm{a}}$ & $78.8^{\mathrm{a}}$ & $78.4^{\mathrm{a}}$ & $75.1^{\mathrm{b}}$ & 0.681 & 0.010 \\
\hline $\mathrm{a}^{*}$ (redness) & $1.82^{\mathrm{b}}$ & $1.86^{\mathrm{b}}$ & $3.31^{\mathrm{a}}$ & $3.15^{\mathrm{a}}$ & 0.215 & 0.004 \\
\hline b* (yellowness) & $17.7^{\mathrm{b}}$ & $18.9^{\mathrm{b}}$ & $21.7^{\mathrm{a}}$ & $22.4^{\mathrm{a}}$ & 0.569 & 0.003 \\
\hline \multicolumn{7}{|l|}{ Measures of rheology } \\
\hline Young's modulus, MPa & 0.358 & 0.397 & 0.359 & 0.346 & 0.038 & 0.799 \\
\hline \multicolumn{7}{|l|}{ Strength to $[\%]$ deformation, $\mathrm{N} / \mathrm{cm}^{2}$} \\
\hline $20 \%$ & 8.19 & 8.80 & 7.87 & 6.94 & 0.760 & 0.442 \\
\hline $40 \%$ & 9.60 & 10.52 & 8.43 & 9.06 & 0.993 & 0.542 \\
\hline $60 \%$ & 12.7 & 13.6 & 11.5 & 11.7 & 1.08 & 0.531 \\
\hline
\end{tabular}

\footnotetext{
${ }^{a, b}$ Means $(\mathrm{n}=3)$ within a row with differing superscripts differ $(P<0.05)$ according to Fisher's least squares difference test.
}

${ }^{1} \mathrm{TN}=$ total nitrogen; WSN $=$ water-soluble nitrogen; PTSN $=$ phosphotungstic acid-soluble nitrogen 
Table 5. Volatile organic compounds detected in Cantal-type cheeses after 9 wk of ripening by solid-phase microextraction-GC/MS [arbitrary units, $\log _{10}\left(\right.$ peak area $\left.\left.\times 10^{-5}\right)\right]$

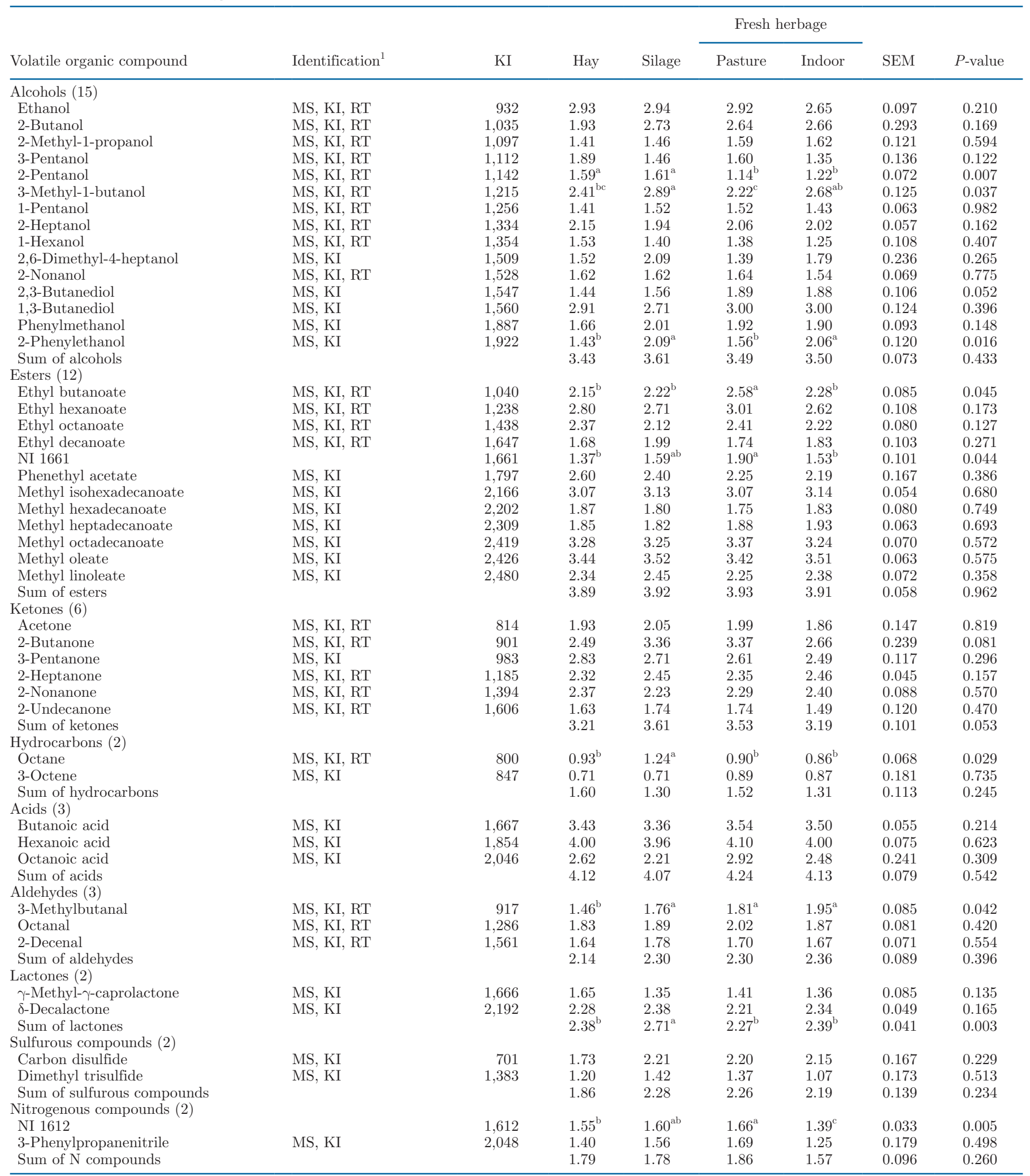

${ }^{\mathrm{a}-\mathrm{c}}$ Means $(\mathrm{n}=3)$ within a row with differing superscripts differ $(P<0.05)$ according to Fisher's least squares difference test.

${ }^{1} \mathrm{MS}$ = identification by comparison with National Institute of Standards and Technology mass spectral data; KI = identification by comparison with Kovats retention index; RT = identification by comparison of retention time; NI = not identified. 
intense $(+0.7 ; P<0.01)$ in cheeses from cows fed fresh herbage than in cheeses from cows fed conserved herbage. Cheeses from grazing cows had a more intense dry fruit flavor $(+0.4 ; P<0.05)$ and weaker lactic odor $(-1.0 ; P<0.05)$ than cheeses from hay- and silage-fed cows. Creamy texture was more pronounced $(+0.6 ; P$ $<0.05)$ when cows were grazing or were fed fresh herbage indoors instead of being fed conserved herbage. No other texture-related characteristics such as softness to the touch and firmness in the mouth differed among treatments.

\section{Relationship Among Sensory and Physicochemical Variables in Cheese}

Increases in the redness $\left(\mathrm{a}^{*}\right)$ and yellowness $\left(\mathrm{b}^{*}\right)$ indexes measured instrumentally in the cheeses led to a positive linear increase in perceived color intensity ( $\mathrm{a}^{*}$ index: $P<0.001, \rho=0.86$; $\mathrm{b}^{*}$ index: $P<0.001, \rho=$ 0.93). The spreadability index (ratio of cis-9-C18:1 to C16:0) was negatively related to instrumentally analyzed strength to $40 \%$ deformation $(P=0.006, \rho=$ -0.74 ) and positively related to the intensity of creamy texture perceived by the panelists $(P=0.014, \rho=0.68)$ and exudate attribute $(P=0.017, \rho=0.67)$. The global flavor intensity was positively related to the barnyard flavor intensity $(P=0.002, \rho=0.79)$. Furthermore, an increase in the PTSN-to-TN ratio in cheese coincided with increasing perception of dry fruit flavor $(P$ $=0.015, \rho=0.68)$ and decreasing perception of lactic odor $(P=0.008, \rho=-0.72)$. Some correlations were also found between sensory attributes of the cheeses and desorbed VOC (Table 8). The concentration of ethyl butanoate was positively correlated with the dry fruit flavor $(P=0.016 ; \rho=0.68)$ and negatively correlated with the lactic odor $(P=0.022 ; \rho=-0.65)$. Ethyl hexanoate, ethyl octanoate, NI (KI 1661), and NI (KI 1612) were positively correlated with the global flavor intensity. In contrast, the concentrations of the methyl esters of isohexadecanoate, oleate, and linoleate were negatively correlated with the global flavor intensity. Ethyl hexanoate was also positively correlated with the global odor intensity of the cheese paste $(P$ $=0.040 ; \rho=0.60)$ as well as with the vegetal flavor $(P=0.030 ; \rho=0.62)$ and the flavor persistence in the mouth $(P=0.030 ; \rho=0.63)$. Lactic flavor intensity was negatively correlated with the concentration of 3 compounds (2-butanone, dimethyl trisulfide, and 2-phenylpropanenitrile). The intensity of the barnyard flavor was positively correlated with the concentration of the NI (KI 1661) compound $(P=0.005 ; \rho=0.77)$, whereas the perception of barnyard odor was negatively

Table 6. Effect of herbage utilization method (HUM) and pasteurization (PAST) on the intensity of sensory attributes of the milk graded from 0 (low intensity) to 10 (high intensity) by 9 trained panelists

\begin{tabular}{|c|c|c|c|c|c|c|c|c|}
\hline Attribute & \multicolumn{4}{|c|}{ HUM } & SEM & \multicolumn{3}{|c|}{$P$-value } \\
\hline \multicolumn{9}{|l|}{ Appearance } \\
\hline Yellowness & $3.60^{\mathrm{c}}$ & $4.50^{\mathrm{b}}$ & $6.19^{\mathrm{a}}$ & $5.66^{\mathrm{a}}$ & 0.216 & $<0.001$ & 0.001 & 0.870 \\
\hline Fluidity & 6.26 & 5.90 & 5.61 & 5.95 & 0.208 & 0.187 & 0.230 & 0.812 \\
\hline \multicolumn{9}{|l|}{ Odor } \\
\hline Cooked milk & $2.04^{\mathrm{c}}$ & $2.37^{\mathrm{bc}}$ & $2.85^{\mathrm{a}}$ & $2.47^{\mathrm{ab}}$ & 0.146 & 0.002 & 0.034 & 0.206 \\
\hline Cream & $2.00^{\mathrm{b}}$ & $2.63^{\mathrm{a}}$ & $2.88^{\mathrm{a}}$ & $2.56^{\mathrm{a}}$ & 0.189 & 0.011 & 0.001 & 0.369 \\
\hline Barnyard & $1.19^{\mathrm{b}}$ & $1.56^{\mathrm{ab}}$ & $1.90^{\mathrm{a}}$ & $1.49^{\mathrm{ab}}$ & 0.179 & 0.049 & 0.039 & 0.910 \\
\hline Hay & 1.07 & 1.29 & 1.45 & 1.15 & 0.150 & 0.292 & 0.951 & 0.638 \\
\hline \multicolumn{9}{|l|}{ Flavor } \\
\hline Intensity & 4.73 & 5.01 & 5.23 & 5.06 & 0.158 & 0.166 & 0.008 & 0.705 \\
\hline Cooked milk & 2.51 & 3.02 & 2.86 & 3.06 & 0.172 & 0.098 & 0.006 & 0.558 \\
\hline Bitter & 1.48 & 1.66 & 1.81 & 1.58 & 0.161 & 0.524 & 0.053 & 0.197 \\
\hline Sweet & 3.49 & 3.66 & 3.25 & 3.48 & 0.190 & 0.501 & 0.439 & 0.580 \\
\hline Metallic & 1.34 & 1.09 & 1.22 & 1.40 & 0.164 & 0.535 & 0.349 & 0.830 \\
\hline Astringent & 1.89 & 1.63 & 1.93 & 1.69 & 0.194 & 0.628 & 0.193 & 0.837 \\
\hline \multicolumn{9}{|l|}{ Texture } \\
\hline Creamy & 3.76 & 4.16 & 4.33 & 4.30 & 0.231 & 0.271 & 0.106 & 0.426 \\
\hline
\end{tabular}

${ }^{\mathrm{a}-\mathrm{c}}$ Means $(\mathrm{n}=6$ per HUM) within a row with differing superscripts differ $(P<0.05)$ between HUM according to Fisher's least squares difference test. 
Table 7. Effect of herbage utilization method on the intensity of sensory attributes of Cantal-type cheeses graded from 0 (low intensity) to 10 (high intensity) by 10 trained panelists after 9 wk of ripening

\begin{tabular}{|c|c|c|c|c|c|c|}
\hline \multirow[b]{2}{*}{ Attribute } & \multirow[b]{2}{*}{ Hay } & \multirow[b]{2}{*}{ Silage } & \multicolumn{2}{|c|}{ Fresh grass } & \multirow[b]{2}{*}{ SEM } & \multirow[b]{2}{*}{$P$-value } \\
\hline & & & Pasture & Indoor & & \\
\hline \multicolumn{7}{|l|}{ Appearance } \\
\hline Color & $1.83^{\mathrm{c}}$ & $2.66^{\mathrm{b}}$ & $3.66^{\mathrm{a}}$ & $3.78^{\mathrm{a}}$ & 0.157 & $<0.001$ \\
\hline Color uniformity & $7.53^{\mathrm{a}}$ & $6.77^{\mathrm{b}}$ & $6.86^{\mathrm{b}}$ & $6.99^{\mathrm{b}}$ & 0.165 & 0.009 \\
\hline Fat exudate & $0.63^{\mathrm{c}}$ & $0.93^{\mathrm{b}}$ & $1.17^{\mathrm{b}}$ & $1.48^{\mathrm{a}}$ & 0.101 & $<0.001$ \\
\hline \multicolumn{7}{|l|}{ Odor } \\
\hline Global intensity (with rind) & 5.79 & 5.78 & 5.96 & 5.82 & 0.184 & 0.899 \\
\hline Global intensity (only paste) & 5.51 & 5.08 & 5.73 & 5.29 & 0.190 & 0.101 \\
\hline Dry fruit/nuts & 2.84 & 2.40 & 2.63 & 2.53 & 0.174 & 0.339 \\
\hline Barnyard & $2.54^{\mathrm{b}}$ & $2.14^{\mathrm{c}}$ & $3.26^{\mathrm{a}}$ & $2.79^{\mathrm{ab}}$ & 0.194 & 0.002 \\
\hline Lactic & $4.76^{\mathrm{a}}$ & $4.80^{\mathrm{a}}$ & $3.82^{\mathrm{b}}$ & $4.28^{\mathrm{ab}}$ & 0.264 & 0.037 \\
\hline Rancid & 1.39 & 1.07 & 1.35 & 1.56 & 0.153 & 0.164 \\
\hline Silage & 2.01 & 1.87 & 1.89 & 2.25 & 0.195 & 0.496 \\
\hline \multicolumn{7}{|l|}{ Taste } \\
\hline Salty & 5.53 & 5.86 & 5.99 & 5.40 & 0.176 & 0.069 \\
\hline Sour & 4.49 & 4.55 & 4.94 & 4.26 & 0.260 & 0.323 \\
\hline Bitter & 3.81 & 3.85 & 3.95 & 3.71 & 0.220 & 0.897 \\
\hline \multicolumn{7}{|l|}{ Flavor } \\
\hline Global intensity & $5.34^{\mathrm{b}}$ & $5.45^{\mathrm{b}}$ & $6.05^{\mathrm{a}}$ & $5.47^{\mathrm{b}}$ & 0.117 & $<0.001$ \\
\hline Dry fruit/nuts & $2.15^{\mathrm{b}}$ & $2.15^{\mathrm{b}}$ & $2.70^{\mathrm{a}}$ & $2.47^{\mathrm{ab}}$ & 0.160 & 0.046 \\
\hline Vegetal & 3.78 & 3.37 & 3.72 & 3.58 & 0.199 & 0.475 \\
\hline Lactic & 3.88 & 3.79 & 3.60 & 4.21 & 0.182 & 0.133 \\
\hline Barnyard & $1.94^{\mathrm{b}}$ & $1.87^{\mathrm{b}}$ & $2.93^{\mathrm{a}}$ & $2.32^{\mathrm{a}}$ & 0.222 & 0.005 \\
\hline Piquant & 2.70 & 2.66 & 3.23 & 2.83 & 0.300 & 0.524 \\
\hline Persistency & 5.04 & 4.90 & 5.35 & 4.89 & 0.219 & 0.422 \\
\hline \multicolumn{7}{|l|}{ Texture } \\
\hline Softness (by touch) & 2.29 & 2.39 & 2.61 & 2.76 & 0.195 & 0.320 \\
\hline Firmness (in the mouth) & 4.73 & 4.51 & 4.35 & 4.64 & 0.192 & 0.526 \\
\hline Creamy & $2.85^{\mathrm{b}}$ & $2.83^{\mathrm{b}}$ & $3.54^{\mathrm{a}}$ & $3.42^{\mathrm{a}}$ & 0.170 & 0.005 \\
\hline Granular & 3.19 & 2.95 & 3.07 & 2.90 & 0.168 & 0.600 \\
\hline Residues (after swallowing) & 3.63 & 3.16 & 3.61 & 3.23 & 0.245 & 0.390 \\
\hline
\end{tabular}

${ }^{\mathrm{a}-\mathrm{c}}$ Means $(\mathrm{n}=3)$ within a row with differing superscripts differ $(P<0.05)$ according to Fisher's least squares difference test.

correlated with the concentration of 2-pentanol $(P=$ $0.042 ; \rho=-0.59)$.

\section{DISCUSSION}

The descriptive sensory analysis in this study included raw and pasteurized milk. Milk pasteurization was previously shown to weaken the dietary effects on the flavor of Cantal-type cheese (Verdier-Metz et al., 2002; Cornu et al., 2009). In the case of milk, we found an increased intensity of odor (cream) and flavor attributes (cooked milk, barnyard) due to pasteurization but no interaction between effects of the herbage utilization method and pasteurization on milk sensory attributes, meaning that raw and pasteurized milk were similarly affected by herbage utilization method. However, pasteurization may have favored the process of oxidation in milk (Havemose et al., 2006), which is consistent with the increased cream and cooked odors of pasteurized milk found independently from the herbage utilization method.

\section{Differences Between Milk and Cheese from Conserved Versus Fresh Herbage}

Although fresh and conserved forages did not originate from the same growing cycle, the potential effect of a diverging botanical composition and phenological stage between the 2 cuts was likely minor. The second growth did not differ in terms of proportions of plant functional groups from the first growth, and the main plant species represented in the 2 growths did not differ greatly. In addition, the phenological stage after 9 wk of regrowth, when bulk milks for cheesemaking were collected, was similar to that given at the time of harvest of the first growth used for hay and silage production.

Color and Texture of Milk and Cheese. The sensory perception of lower yellowness of the milk and the instrumental yellowness of the cheese from groups fed conserved forages accord with the previously observed lower content of carotenoids in milk from silage-fed cows and especially from hay-fed cows (Nozière et al., 2006). Carotenoids are depleted through photo-oxidation dur- 
ing herbage wilting and conservation, and the milk's carotenoid content is directly related to the carotenoid intake (Nozière et al., 2006). The observed increase in fat exudation from cheese when cows were fed fresh herbage instead of conserved forages can be explained by the observed lower proportion of SFA and higher proportions of PUFA and MUFA in milk resulting in a lower fat melting point (Frétin et al., 2017). This explanation is also supported by the linear relationship of the spreadability index (ratio of cis-9-C18:1 to C16:0) with the creamy texture and instrumental texture traits in the present experiment. In addition, a higher PUFA proportion of the milk fat seems to be associated with an increased polarity of the fat globule membrane. This increased polarity lowers the membrane's cohesion and consequently leads to a higher propension of milk fat globule membranes to disrupt during cheesemaking (Lopez et al., 2008; Lerch et al., 2015), which may help to explain the increased fat exudation of the cheeses from cows fed fresh herbage.

Milk Odor and Flavor. The differences found in the odor of the milk from cows fed conserved or fresh grass are consistent with previous reports in literature (Faulkner et al., 2018; Clarke et al., 2019). The percep- tion of a stronger cooked odor in milk from cows fed fresh herbage may be associated with an increased presence of sulfurous compounds. Dimethyl disulfide and its oxidation product dimethyl sulfone were found to be more abundant in milk from grazing animals than in milk from cows fed hay- or TMR-based diets (Moio et al., 1993; Coppa et al., 2011b; Villeneuve et al., 2013). Sulfurous compounds typically derive from the metabolism of sulfurous AA. Indeed, in contrast to conserved forages, diets based on fresh herbage were found to increase VOC formation from the metabolism of free AA by rumen microorganisms as a result of the higher ratio of protein to readily digestible carbohydrates (Bendall, 2001; Coppa et al., 2011b). Cooked and cream odors of the milk may also be related to lactones, which were previously found to be more abundant in milk from grazing cows compared with milk from TMR-fed cows (Bendall, 2001). Lactones are formed during the primary oxidation of PUFA (Urbach, 1990). Consistent with this, the proportions of LA and ALA were numerically higher in the lipids of the fresh than the conserved forages. Furthermore, ruminal lipolysis and rate of biohydrogenation of dietary lipids were reported to be higher with fresh herbage than with conserved

Table 8. Pearson correlation coefficients $(\rho)$ between the intensity of sensory attributes and concentration of desorbed volatile organic compounds of Cantal-type cheeses after 9 wk of ripening

\begin{tabular}{llrr}
\hline Sensory attribute & Volatile organic compound ${ }^{1}$ & $\rho$ & $P$-value \\
\hline Global odor intensity (with rind) & 1,3-Butanediol & 0.61 & 0.036 \\
& Sum of N compounds & 0.66 & 0.019 \\
Global odor intensity (only paste) & Ethyl hexanoate & 0.60 & 0.040 \\
Barnyard odor & 2-Pentanol & -0.59 & 0.042 \\
& Sum of lactones & -0.60 & 0.039 \\
Lactic odor & Ethyl butanoate & -0.65 & 0.022 \\
Global flavor intensity & Ethyl hexanoate & 0.66 & 0.019 \\
& Ethyl octanoate & 0.61 & 0.033 \\
& NI (KI 1661) & 0.86 & $<0.001$ \\
& NI (KI 1612) & 0.69 & 0.010 \\
& Methyl isohexadecanoate & -0.59 & 0.040 \\
& Methyl oleate & -0.59 & 0.040 \\
Dry fruit flavor & Methyl linoleate & -0.67 & 0.020 \\
& Ethyl butanoate & 0.68 & 0.016 \\
Vegetal flavor & 3-Pentanone & -0.60 & 0.040 \\
& Methyl hexadecanoate & -0.63 & 0.028 \\
& Ethyl hexanoate & 0.62 & 0.030 \\
Lactic flavor & -Methyl- $\gamma$-caprolactone & 0.63 & 0.028 \\
& Octanoic acid & 0.70 & 0.012 \\
Barnyard flavor & 2-Heptanone & -0.68 & 0.013 \\
Piquant flavor & 2-Butanone & -0.58 & 0.044 \\
& Dimethyl trisulfide & -0.65 & 0.020 \\
Flavor persistency & 3-Phenylpropanenitrile & -0.72 & 0.028 \\
\hline & NI (KI 1661) & 0.77 & 0.005 \\
& 1-Pentanol & -0.75 & 0.020 \\
& 2-Methyl-1-propanol & 0.59 & 0.045 \\
& Ethyl hexanoate & 0.66 & 0.020 \\
& 2-Heptanol & -0.58 & 0.045 \\
& Ethyl hexanoate & 0.63 & 0.030 \\
\hline
\end{tabular}

${ }^{1} \mathrm{NI}=$ not identified; $\mathrm{KI}=$ identification by comparison with Kovats retention index. 
likely because endogenous plant lipases are more active in the first (Doreau et al., 2005; Dewhurst et al., 2006; van Dorland et al., 2008). Among the evaluated sensory attributes, a more intense barnyard odor also characterized milk from grazing cows compared with milk from hay-fed cows. This finding is considered to be associated with the increased presence of derivatives of phenols, indoles, and terpenoids such as $p$-cresol, phytol, indole, and skatole (Urbach, 1990; Moio et al., 1996; Bendall, 2001). These compounds result from the ruminal degradation of free aromatic $\mathrm{AA}$ and plant compounds such as carotenoids, flavonoids, and chlorophyll in the herbage (Yokoyama and Carlson, 1981; Moio et al., 1993). Toluene, a highly volatile aromatic hydrocarbon deriving from the degradation of $\beta$-carotene, may have especially contributed to the stronger odor intensity of milk from fresh herbage, although it has a high odor threshold. The VOC characteristic for the milk did not desorb from the cheeses in the present experiment because their putative presence in milk has most probably been modified during cheesemaking and cheese ripening. Indeed, cheese ripening causes enormous changes in the concentration of VOC in relation to the milk used for cheesemaking (Cornu et al., 2009; Bergamaschi and Bittante, 2018).

Cheese Odor and Flavor. In accordance with previous studies, the global flavor of cheeses obtained from grazing cows in the present experiment was perceived to be more intense than that of the cheeses from cows fed conserved forages (Coppa et al., 2011c; Esposito et al., 2014; Giaccone et al., 2016). The main VOC that desorbed from the experimental cheeses were consistent with those previously reported in Cantal-type cheese (Frétin et al., 2019). Among the identified compounds, a few were previously described by GC-olfactometry as being odor active in Cantal-type cheeses (Cornu et al., 2009). These compounds were ethanol, butanoic acid, 3-methylbutanal, octanal, 2-nonanone, and 2-phenylethanol. The negative correlation between the desorbed amounts of 3 compounds (2-butanone, dimethyl trisulfide, and 3-phenylpropanenitrile) and the intensity of the lactic flavor is consistent with the observation that cheeses with more intense lactic flavor were characterized by a slower catabolism of free AA and free FA and possibly reduced formation of VOC (McSweeney and Sousa, 2000). The correlation also coincides with the differences in global flavor intensity perceived by the panelists. Dimethyl trisulfide and 2-butanone are also relevant flavor compounds in other cheeses varieties, whereby the first derives from the degradation of free sulfurous AA and the second from 2,3-butanediol (McSweeney and Sousa, 2000). The global flavor intensity was negatively correlated with oleate, linoleate, and isohexadecanoate methyl esters, which are compounds characterized by rather faint fatty odors and flavors (Garg et al., 2018). The concentration of these methyl esters may decrease along with increasing catabolism of free FA methyl esters in cheese.

The barnyard flavor, which characterized cheeses from both groups fed fresh herbage, greatly contributed to their global flavor intensity. The mentioned compounds putatively responsible for barnyard flavor in milk (e.g., p-cresol) are rarely identified in Cantaltype cheeses. In our experiment, none of the mentioned compounds was detected in the headspace of the Cantal cheese. However, an unidentified compound (KI 1661, putatively a branched-chain ester) was positively correlated with the intensity of the barnyard flavor in the cheeses. In accordance with previous observations (Martin et al., 2005; Giaccone et al., 2016), the dry fruit flavor was more intense in cheeses derived from grazing cows compared with cheeses from cows fed conserved forages in the present experiment. The intensity of the dry fruit flavor was positively related to the concentration of ethyl butanoate, which is characterized by a strong sweet, ripe fruit flavor (Garg et al., 2018). Accordingly, the fruity and nutty flavor found in Cantaltype cheeses from cows grazing on upland pastures was related by Cornu et al. (2009) to the increased presence of short-chain FA methyl esters (e.g., methyl hexanoate). These FA methyl esters may result from the incomplete esterification of FA to triacylglycerols in the mammary gland or from the increased lipolysis in milk (Cornu et al., 2009). Also aldehydes resulting from the proteolysis and subsequent degradation of free AA are associated with the dry fruit flavor, which was previously reported for Cheddar-type cheeses (Avsar et al., 2004). Indeed, 3-methyl-butanal, which has a specific nutty flavor, was higher in concentration in cheeses from grazing cows in the present study, too. Consistently, the increased secondary proteolysis (PTSN-to-TN ratio) coincided with increased intensity of dry fruit flavor in cheeses in the present experiment. We found similar concentrations of 3-phenylpropanenitrile in all cheeses. This compound may have originated from the rapeseed meal contained in the concentrate because 3-phenylpropanenitrile is a breakdown product of glucosinolates commonly found in Brassicaceae (Gu et al., 2011). The increased content of $\mathrm{Mg}$ in milk from cows fed fresh herbage may be due to a higher content or higher bioavailability of $\mathrm{Mg}$ in fresh herbage than in conserved forages fed in the present experiment or a higher $\mathrm{Mg}$ content in the herbage of the second growing cycle (Schlegel et al., 2016), but it was not correlated with any other compositional, technological, rheological, or sensory variable. 


\section{Differences Between Milk and Cheese from Cows Fed Hay or Silage}

The results of our experiment confirm that feeding properly conserved and fed silage does not cause offflavors in milk and cheese. This finding may not hold true when the conservation quality of the forages is poor or feeding is not performed according to good farming practice (Mounchili et al., 2005). Using triangle tests, Dubroeucq et al. (2002) detected sensory differences in raw milk from cows fed mountain grassland hay or ryegrass silage. In contrast, panelists perceived no differences in pasteurized milk from cows fed timothy grass conserved either as hay or as silage in the study of Villeneuve et al. (2013). In our experiment, milk from silage-fed cows had a stronger cream odor than milk from hay-fed cows. This outcome may have resulted from the higher proportion of PUFA (LA and ALA, in particular) in the silage lipids, followed by increased lipolysis and biohydrogenation of PUFA in the rumen when herbage is conserved as silage (Doreau et al., 2005). The higher PUFA proportion of the forage lipids may also enhance the formation of VOC such as lactones from primary lipid oxidation in milk (Havemose et al., 2006) and affect the availability of precursors of VOC that are characteristic for cream flavor. Consistent with this possibility, the concentration of total lactones was higher in cheeses from silage-fed cows compared with those from hay-fed cows. In addition, the concentrations of 3-methyl-1-butanol and 2-phenylethanol were higher in cheeses from silage-fed cows than in cheese from hay-fed cows. Both compounds may derive from the catabolism of free AA such as 2-phenylethanol from the catabolism of Phe, whereas 3-methyl-1-butanol may arise from the Strecker degradation of Leu (McSweeney and Sousa, 2000). In addition, the concentration of 3 -methylbutanal, the aldehyde precursor of 3-methyl1-butanol, was higher in cheeses from silage-fed cows than those from hay-fed cows. This finding may be an indication of a different AA catabolism in cheeses from silage- or hay-fed cows due to different microbial activity. Ethanol that commonly results from silage fermentation and may be directly transferred to milk did not differ in concentration between cheeses, in accordance with Stefanon and Procida (2004). We observed no differences in the intensity of flavor descriptors of the cheeses between herbage conservation methods, which substantiates previous findings by Verdier-Metz et al. (1998) on Saint-Nectaire cheeses derived from cows fed hay and silage from the same plot of native mountain grassland. In contrast, studies of Verdier-Metz et al. (2005) and Serrapica et al. (2020) reported some flavor differences related to the herbage conservation method. Such sensory differences may be due to a different dietary proportion of dicotyledonous species (ryegrass silage from temporary grassland versus permanent grassland hay; Verdier-Metz et al., 2005), or they could be related to the specific forage types (i.e., sorghum) and the specific processing technology of stretched curd cheeses (Serrapica et al., 2020). Similar to the study by Verdier-Metz et al. (1998), the present experiment avoided this effect by using herbage from the same permanent grassland for hay- and silage-making. As demonstrated by Stefanon and Procida (2004) for pressed cooked Montasio cheeses, it seems that sensory differences between cheeses from either hay- or silagefed cows are mostly related to microbial processes occurring in milk and in ripening cheese. These differences may be even more pronounced in uncooked than in cooked pressed cheeses, but this possibility was not investigated in the present study. In addition, the slight differences in milk FA profile of hay- or silagefed cows did not substantially affect the development of particular flavor notes, whereas cheese appearance (i.e., fat exudation) differed, as was observed earlier in Cantal-type cheeses from cows fed pasture versus hay or from pasture versus a maize silage-based diet (Coppa et al., 2011a,c; Frétin et al., 2019).

\section{Differences Between Milk and Cheese from Grazing and Indoor Green-Fed Cows}

To our knowledge, this study is the first to report differences in sensory properties of milk and cheese from grazing versus indoor green-fed cows. The global flavor intensity of the cheeses from the grazing cows was higher than that of the indoor green-fed cows. The proportion of grasses, legumes, and nonlegume forbs in the selected bites did not differ from the proportions in the fresh herbage offered indoors, as strip-grazing may have limited the extensive dietary selection of the grazing cows (Coppa et al., 2015a). Therefore, no general variation in forage selection behavior of the cows appears to have been responsible for the difference in global flavor intensity. The SCC in milk as well as the degree of lipolysis in milk and cheese did not differ between grazing and indoor green-fed cows. This finding was unexpected because walking from and to pasture before and after milking may induce an increased SCC (Koczura et al. 2019) that may be associated with an increased lipolysis of the milk fat of grazing cows and consequently increase the availability of free FA particularly susceptible to oxidation in the cheese. However, in the present study the pasture was very near to the barn, which may have limited this effect; it may still be relevant elsewhere. On the other hand, under similar grazing conditions Ferlay et al. (2006) found a lower lipolytic activity in milk from grazing cows compared 
with cows fed conserved herbages indoor, but no direct comparison to indoor-green fed cows was ever reported in the literature. Dewhurst et al. (2006) described that plants respond to stress such as cutting, biting, and chewing by rapid activation of endogenous lipases, which leads to release of nonesterified FA, especially ALA and LA, from the lipid membranes. Lipoxygenases catalyze the hydroxyperoxidation of PUFA and the subsequent formation of volatile straight-chain aldehydes and alcohols on the field and in the rumen, as shown in vitro (Dewhurst et al., 2006; Huws et al., 2013). The level of such stress imposed on the plants may differ between grazing and indoor green-feeding and thereby affect the formation of odor-active compounds in the rumen or later in the milk. In addition, differences in feed intake behavior, such as the ingestion of larger boluses, the reduced chewing time, and the lower secretion of saliva per bolus of indoor green-fed cows compared with cows grazing the same herbage (Boudon et al., 2006) may have an influence. The reduced chewing time may slow the release of plant intracellular compounds and the synchronous availability of rumen-degradable $\mathrm{CP}$ and energy for the microbial metabolism in the rumen (Boudon et al., 2006). Such an imbalance might be the origin of a reduced synthesis of flavor compounds and consequently lead to the weaker global flavor intensity of cheeses from the indoor green-fed group. The concentrations of 2 esters [ethyl butanoate and NI (KI 1612)] were higher and those of 2 alcohols (2-phenylethanol and 3-methyl-1-butanol) were lower in cheese from grazing cows than in cheese from indoor green-fed cows. As previously described, both esters and alcohols mainly derive from the microbial metabolism and AA catabolism, which may have differed between the cheeses of the 2 groups. In fact, although the cows were milked by the same procedure and total bacterial counts in milk did not differ between groups, it cannot be excluded that the number and variety of microbial species in the raw milk differed. Keeping cows on pasture seems to increase the variety of microbial strains on the teat-skin surface and in milk in comparison with indoor housing (Verdier-Metz et al., 2012). Furthermore, the microbial diversity of the teat skin is affected by the grazing system (Frétin et al., 2018). Strong evidence also exists for an impact of the indigenous microbial community of raw milk on the development of flavors and texture in uncooked pressed cheeses (Callon et al., 2005). Therefore, the difference in global flavor intensity between cheeses from grazing cows and all other cheeses putatively associated with the increased ethyl butanoate concentration may have been related to differences in microbial species variety in the milk's native microflora caused by the different environments where the animals were kept. Additional research is needed to understand the effect of different feeding systems on the raw milk microbiota, its transfer to cheese, and the consequences for the sensory properties of ripened cheese.

\section{CONCLUSIONS}

The herbage utilization method was found to affect composition and sensory characteristics of milk and cheese, even when the botanical composition of the forages and the plot origin were the same. Cheese from cows fed fresh herbage clearly differed in sensory properties from that of cows fed conserved forages. Sensory differences of milk and cheese from cows fed either hay or silage were limited to appearance attributes (cheese from hay-fed cows being whiter) and less pronounced in odor and flavor. This outcome points toward a limited effect of the ensiling or drying process itself. However, under practical conditions the effect of herbage conservation methods is strongly interrelated with grassland management practices, especially with the botanical composition and phenological stage of the herbage at harvest because the herbage for silage-making is typically harvested earlier than that for haymaking. An important result was that the flavor intensity of cheeses from indoor green-fed cows was more similar to that of cheeses obtained from cows fed conserved forages than cheeses from grazing cows, whereas milk and cheese composition were otherwise quite similar between the 2 groups fed fresh herbage. The possible distinction of dairy products from grazing and indoor green-fed cows is interesting for consideration for inclusion in producer's specifications for labeled dairy products, which is already practiced by some protected designation of origin specifications.

\section{ACKNOWLEDGMENTS}

We thank all those helping during the experiment, in particular R. Lavigne and F. Allegretti for cheesemaking (INRAE, Aurillac, France); F. Fournier, P. Tardif, and O. Troquier for the technical assistance (INRAE, Marcenat, France); and L. Garraud and C. Labonne (INRAE, Theix, France), as well as E. Marchi (Università di Parma, Italy) for the laboratory analysis. Many thanks also to the panelists participating in the sensory evaluations. The financial support provided by the Transnational Access to Research Infrastructure activity in the Horizon 2020 Program of the European Commission (Project "SmartCow," no.730924), the H. Wilhelm Schaumann Foundation (Hamburg, Germany), and the French government IDEX-ISITE initiative 16-IDEX-0001 (CAP 20-25) is gratefully acknowledged. The authors have not stated any conflicts of interest. 


\section{REFERENCES}

AFNOR. 2002. AFNOR NF V 04-287. Détermination de la teneur en matière grasse - Méthode acido-butyrométrique - Part 2 Technique de Heiss. Association française de normalization (AFNOR).

Akert, F. S., K. Dorn, H. Frey, P. Hofstetter, J. Berard, M. Kreuzer, and B. Reidy. 2020. Farm-gate nutrient balances of grasslandbased milk production systems with full- or part-time grazing and fresh herbage indoor feeding at variable concentrate levels. Nutr. Cycl. Agroecosyst. 117:383-400. https://doi.org/10.1007/s10705 -020-10072-y.

Ardö, Y. 1999. Evaluating proteolysis by analysing the N content of cheese fractions. Bull. Int. Dairy Fed. 337:4-7.

Avsar, Y. K., Y. Karagul-Yuceer, M. A. Drake, T. K. Singh, Y. Yoon, and K. R. Cadwallader. 2004. Characterization of nutty flavor in Cheddar cheese. J. Dairy Sci. 87:1999-2010. https://doi.org/10 .3168/jds.S0022-0302(04)70017-X.

Bendall, J. G. 2001. Aroma compounds of fresh milk from New Zealand cows fed different diets. J. Agric. Food Chem. 49:4825-4832. https://doi.org/10.1021/jf010334n.

Bergamaschi, M., and G. Bittante. 2018. From milk to cheese: Evolution of flavor fingerprint of milk, cream, curd, whey, ricotta, scotta, and ripened cheese obtained during summer Alpine pasture. J. Dairy Sci. 101:3918-3934. https://doi.org/10.3168/jds.2017-13573.

Bianchi, F., M. Careri, A. Mangia, and M. Musci. 2007. Retention indices in the analysis of food aroma volatile compounds in temperature-programmed gas chromatography: Database creation and evaluation of precision and robustness. J. Sep. Sci. 30:563-572. https://doi.org/10.1002/jssc.200600393.

Boudon, A., A. Acosta, R. Delagarde, and J. L. Peyraud. 2006. Release of cell contents and comminution of particles of perennial ryegrass herbage during ingestion by dairy cows fed indoors or grazing. Grass Forage Sci. 61:205-217. https://doi.org/10.1111/j .1365-2494.2006.00526.x

Butler, G., J. H. Nielsen, M. K. Larsen, B. Rehberger, S. Stergiadis, A. Canever, and C. Leifert. 2011. The effects of dairy management and processing on quality characteristics of milk and dairy products. NIJAS-Wagen. J. Life Sci. 58:97-102. https://doi.org/10 .1016/j.njas.2011.04.002.

Callon, C., J. L. Berdagué, E. Dufour, and M. C. Montel. 2005. The effect of raw milk microbial flora on the sensory characteristics of Salers-type cheeses. J. Dairy Sci. 88:3840-3850. https://doi.org/10 .3168/jds.S0022-0302(05)73069-1.

Clarke, H. J., C. Griffin, D. K. Rai, T. F. O'Callaghan, M. G. O'Sullivan, J. P. Kerry, and K. N. Kilcawley. 2019. Dietary compounds influencing the sensorial volatile and phytochemical properties of bovine milk. Molecules 25:26. https://doi.org/10.3390/ molecules25010026.

Coppa, M., A. Farruggia, P. Ravaglia, D. Pomiès, G. Borreani, A. Le Morvan, and A. Ferlay. 2015a. Frequent moving of grazing dairy cows to new paddocks increases the variability of milk fatty acid composition. Animal 9:604-613. https://doi.org/10.1017/ S1751731114003000.

Coppa, M., A. Ferlay, G. Borreani, A. Revello-Chion, E. Tabacco, G. Tornambé, P. Pradel, and B. Martin. 2015b. Effect of phenological stage and proportion of fresh herbage in cow diets on milk fatty acid composition. Anim. Feed Sci. Technol. 208:66-78. https://doi .org/10.1016/j.anifeedsci.2015.07.006.

Coppa, M., A. Ferlay, F. Monsallier, I. Verdier-Metz, P. Pradel, R. Didienne, A. Farruggia, M. C. Montel, and B. Martin. 2011a. Milk fatty acid composition and cheese texture and appearance from cows fed hay or different grazing systems on upland pastures. J. Dairy Sci. 94:1132-1145. https://doi.org/10.3168/jds.2010-3510.

Coppa, M., B. Martin, P. Pradel, B. Leotta, A. Priolo, and V. Vasta. 2011b. Effect of hay-based diet or different upland grazing systems on milk volatile compounds. J. Agric. Food Chem. 59:4947-4954. https://doi.org/10.1021/jf2005782.

Coppa, M., I. Verdier-Metz, A. Ferlay, P. Pradel, R. Didienne, A. Farruggia, M. C. Montel, and B. Martin. 2011c. Effect of different grazing systems on upland pastures compared with hay diet on cheese sensory properties evaluated at different ripening times. Int. Dairy J. 21:815-822. https://doi.org/10.1016/j.idairyj.2011.04 .006 .

Cornu, A., N. Rabiau, N. Kondjoyan, I. Verdier-Metz, P. Pradel, P. Tournayre, J. L. Berdagué, and B. Martin. 2009. Odour-active compound profiles in Cantal-type cheese: Effect of cow diet, milk pasteurization and cheese ripening. Int. Dairy J. 19:588-594. https: //doi.org/10.1016/j.idairyj.2009.04.008.

Daget, P., and J. Poissonet. 1969. Analyse phytologique des prairies. Ann. Agron. 22:5-41.

Dewhurst, R. J., K. J. Shingfield, M. R. F. Lee, and N. D. Scollan. 2006. Increasing the concentrations of beneficial polyunsaturated fatty acids in milk produced by dairy cows in high-forage systems. Anim. Feed Sci. Technol. 131:168-206. https://doi.org/10.1016/j .anifeedsci.2006.04.016.

Doreau, M., M. R. F. Lee, K. Ueda, and N. D. Scollan. 2005. Ruminal metabolism and absorption of fatty acids from forages. Renc. Rech. Rum. 12:101-104.

Dubroeucq, H., B. Martin, A. Ferlay, P. Pradel, I. Verdier-Metz, Y. Chilliard, J. Agabriel, and J. B. Coulon. 2002. Cow's feeding may modify sensory properties of milk. Renc. Rech. Rum. 9:351-354.

Dumont, B., J. C. J. Groot, and M. Tichit. 2018. Review: Make ruminants green again - How can sustainable intensification and agroecology converge for a better future? Animal 12(s2):s210-s219. https://doi.org/10.1017/S1751731118001350.

Esposito, G., F. Masucci, F. Napolitano, A. Braghieri, R. Romano, N. Manzo, and A. Di Francia. 2014. Fatty acid and sensory profiles of Caciocavallo cheese as affected by management system. J. Dairy Sci. 97:1918-1928. https://doi.org/10.3168/jds.2013-7292.

Faulkner, H., T. F. O'Callaghan, S. McAuliffe, D. Hennessy, C. Stanton, M. G. O'Sullivan, J. P. Kerry, and K. N. Kilcawley. 2018. Effect of different forage types on the volatile and sensory properties of bovine milk. J. Dairy Sci. 101:1034-1047. https://doi.org/10 $.3168 /$ jds.2017-13141.

Ferlay, A., B. Martin, S. Lerch, M. Gobert, P. Pradel, and Y. Chilliard. 2010. Effect of supplementation of maize silage diets with extruded linseed, vitamin $\mathrm{E}$ and plant extracts rich in polyphenols, and morning vs. evening milking on milk fatty acid profile in Holstein and Montbéliarde cows. Animal 4:627-640. https://doi.org/ 10.1017/S1751731109991224.

Ferlay, A., B. Martin, P. Pradel, J. B. Coulon, and Y. Chilliard. 2006. Influence of grass-based diets on milk fatty acid composition and milk lipolytic system in Tarentaise and Montbéliarde cow breeds. J. Dairy Sci. 89:4026-4041. https://doi.org/10.3168/jds.S0022 -0302(06)72446-8.

Frétin, M., A. Ferlay, I. Verdier-Metz, F. Fournier, M. C. Montel, A. Farruggia, C. Delbès, and B. Martin. 2017. The effects of lowinput grazing systems and milk pasteurisation on the chemical composition, microbial communities, and sensory properties of uncooked pressed cheeses. Int. Dairy J. 64:56-67. https://doi.org/10 .1016/j.idairyj.2016.09.007.

Frétin, M., B. Martin, S. Buchin, B. Desserre, R. Lavigne, E. Tixier, C. Cirié, C. Bord, M. C. Montel, C. Delbés, and A. Ferlay. 2019. Milk fat composition modifies the texture and appearance of Cantal-type cheese but not their flavor. J. Dairy Sci. 102:1131-1143. https://doi.org/10.3168/jds.2018-15534.

Frétin, M., B. Martin, E. Rifa, V. M. Isabelle, D. Pomiès, A. Ferlay, M. C. Montel, and C. Delbès. 2018. Bacterial community assembly from cow teat skin to ripened cheeses is influenced by grazing system. Sci. Rep. 8:200. https://doi.org/10.1038/s41598-017-18447-y.

Garg, N., A. Sethupathy, R. Tuwani, R. Nk, S. Dokania, A. Iyer, A Gupta, S. Agrawal, N. Singh, S. Shukla, K. Kathuria, R. Badhwar, R. Kanji, A. Jain, A. Kaur, R. Nagpal, and G. Bagler. 2018. FlavorDB: A database of flavor molecules. Nucleic Acids Res. 46(D1):D1210-D1216. https://doi.org/10.1093/nar/gkx957.

Giaccone, D., A. Revello-Chion, L. Galassi, P. Bianchi, G. Battelli, M. Coppa, E. Tabacco, and G. Borreani. 2016. Effect of milk thermisation and farming system on cheese sensory profile and fatty acid composition. Int. Dairy J. 59:10-19. https://doi.org/10.1016/ j.idairyj.2016.02.047. 
Gu, X., W. Dong, and Y. He. 2011. Detoxification of rapeseed meals in steam explosion. J. Am. Oil Chem. Soc. 88:1831-1838. https:// doi.org/10.1007/s11746-011-1852-6.

Hack, H., H. Bleiholder, L. Buhr, U. Meier, U. Schnock-Fricke, E. Weber, and A. Witzenberger. 1992. A uniform code for phenological growth stages of mono-and dicotyledonous plants-Extended BBCH scale, general. Nachr. Dtsch. Pflanzenschutzd. 44:265-270.

Halmemies-Beauchet-Filleau, A., P. Kairenius, S. Ahvenjärvi, V. Toivonen, P. Huhtanen, A. Vanhatalo, D. I. Givens, and K. J. Shingfield. 2013. Effect of forage conservation method on plasma lipids, mammary lipogenesis, and milk fatty acid composition in lactating cows fed diets containing 60:40 forage-to-concentrate ratio. J. Dairy Sci. 96:5267-5289. https://doi.org/10.3168/jds.2013 $-6571$.

Havemose, M. S., M. R. Weisbjerg, W. L. Bredie, H. D. Poulsen, and J. H. Nielsen. 2006. Oxidative stability of milk influenced by fatty acids, antioxidants and copper derived from feed. J. Dairy Sci. 89:1970-1980. https://doi.org/10.3168/jds.S0022-0302(06)72264 -0 .

Huws, S. A., M. B. Scott, J. K. S. Tweed, and M. R. F. Lee. 2013. Fatty acid oxidation products ("green odour") released from perennial ryegrass following biotic and abiotic stress, potentially have antimicrobial properties against the rumen microbiota resulting in decreased biohydrogenation. J. Appl. Microbiol. 115:1081-1090. https://doi.org/10.1111/jam.12314.

ISO. 2004a. ISO 1740: Milkfat products and butter-Determination of acidity (Reference method). International Organization for Standardization, Geneva, Switzerland.

ISO. 2004b. ISO 5534: Cheese and processed cheese-Determination of the total solid content (Reference method). International Organization for Standardization, Geneva, Switzerland.

ISO. 2006. ISO 5943: Cheeses and processed cheese products-Determination of chloride content- Potentiometric titration method. International Organization for Standardization, Geneva, Switzerland.

ISO. 2012. ISO 8586-1: Sensory analysis - General guidelines for the selection, training and monitoring of selected assessors and expert sensory assessors. International Organization for Standardization, Geneva, Switzerland.

ISO. 2014. ISO 8968-1: Milk and milk products-Determination of nitrogen content-Part 1: Kjeldahl principle and crude protein calculation. International Organization for Standardization, Geneva, Switzerland.

Kilcawley, K. N., H. Faulkner, H. J. Clarke, M. G. O'Sullivan, and J. P. Kerry. 2018. Factors influencing the flavour of bovine milk and cheese from grass based versus non-grass based milk production systems. Foods 7:37. https://doi.org/10.3390/foods7030037.

Koczura, M., B. Martin, G. Turille, M. De Marchi, M. Kreuzer, and J. Berard. 2019. Milk composition, but not cheese properties, are impaired the day after transhumance to alpine pastures. Int. Dairy J. 99:104540. https://doi.org/10.1016/j.idairyj.2019.104540.

Leiber, F., M. Kreuzer, D. Nigg, H. R. Wettstein, and M. R. L. Scheeder. 2005. A study on the causes for the elevated n-3 fatty acids in cows' milk of alpine origin. Lipids 40:191-202. https://doi.org/10 .1007/s11745-005-1375-3.

Lerch, S., A. Ferlay, B. Graulet, C. Cirié, I. Verdier-Metz, M. C. Montel, Y. Chilliard, and B. Martin. 2015. Extruded linseeds, vitamin $\mathrm{E}$ and plant extract in corn silage-based diets of dairy cows: Effects on sensory properties of raw milk and uncooked pressed cheese. Int. Dairy J. 51:65-74. https://doi.org/10.1016/j.idairyj.2015.07 .006 .

Lopez, C., V. Briard-Bion, O. Menard, F. Rousseau, P. Pradel, and J. M. Besle. 2008. Phospholipid, sphingolipid, and fatty acid compositions of the milk fat globule membrane are modified by diet. J. Agric. Food Chem. 56:5226-5236. https://doi.org/10.1021/ jf7036104.

Manzocchi, E., W. Hengartner, M. Kreuzer, and K. Giller. 2020. Effect of feeding hay vs. silages of various types to dairy cows on feed intake, milk composition and coagulation properties. J. Dairy Res. 87:334-340. https://doi.org/10.1017/S0022029920000801.
Martin, B., C. Hurtaud, B. Graulet, A. Ferlay, Y. Chilliard, and J. B. Coulon. 2009a. Grass and the nutritional and organoleptic qualities of dairy products. Fourrages (Versailles) 199:291-310.

Martin, B., D. Pomiès, P. Pradel, I. Verdier-Metz, and B. Rémond. 2009b. Yield and sensory properties of cheeses made with milk from Holstein or Montbéliarde cows milked twice or once daily. J. Dairy Sci. 92:4730-4737. https://doi.org/10.3168/jds.2008-1914.

Martin, B., I. Verdier-Metz, S. Buchin, C. Hurtaud, and J. B. Coulon. 2005. How do the nature of forages and pasture diversity influence the sensory quality of dairy livestock products? Anim. Sci. 81:205-212. https://doi.org/10.1079/ASC50800205.

McSweeney, P. L. H., and M. J. Sousa. 2000. Biochemical pathways for the production of flavour compounds in cheeses during ripening: A review. Lait 80:293-324. https://doi.org/10.1051/lait:2000127.

Mohammed, R., C. S. Stanton, J. J. Kennelly, J. K. G. Kramer, J. F. Mee, D. R. Glimm, M. O'Donovan, and J. J. Murphy. 2009. Grazing cows are more efficient than zero-grazed and grass silage-fed cows in milk rumenic acid production. J. Dairy Sci. 92:3874-3893. https://doi.org/10.3168/jds.2008-1613.

Moio, L., J. Dekimpe, P. Etievant, and F. Addeo. 1993. Neutral volatile compounds in the raw milks from different species. J. Dairy Res. 60:199-213. https://doi.org/10.1017/S0022029900027515.

Moio, L., L. Rillo, A. Ledda, and F. Addeo. 1996. Odorous constituents of ovine milk in relationship to diet. J. Dairy Sci. 79:1322-1331. https://doi.org/10.3168/jds.S0022-0302(96)76488-3.

Mounchili, A., J. J. Wichtel, J. O. Bosset, I. R. Dohoo, M. Imhof, D. Altieri, S. Mallia, and H. Stryhn. 2005. HS-SPME gas chromatographic characterization of volatile compounds in milk tainted with off-flavour. Int. Dairy J. 15:1203-1215. https://doi.org/10 .1016/j.idairyj.2004.11.018.

Nozière, P., B. Graulet, A. Lucas, B. Martin, P. Grolier, and M. Doreau. 2006. Carotenoids for ruminants: From forages to dairy products. Anim. Feed Sci. Technol. 131:418-450. https://doi.org/ 10.1016/j.anifeedsci.2006.06.018.

Penasa, M., M. De Marchi, S. Ton, L. Ancilotto, and M. Cassandro. 2015. Reproducibility and repeatability of milk coagulation properties predicted by mid-infrared spectroscopy. Int. Dairy J. 47:1-5. https://doi.org/10.1016/j.idairyj.2015.02.004.

Schlegel, P., U. Wyss, Y. Arrigo, and H. D. Hess. 2016. Mineral concentrations of fresh herbage from mixed grassland as influenced by botanical composition, harvest time and growth stage. Anim. Feed Sci. Technol. 219:226-233. https://doi.org/10.1016/j.anifeedsci .2016.06.022.

Serrapica, F., P. Uzun, F. Masucci, F. Napolitano, A. Braghieri, A. Genovese, R. Sacchi, R. Romano, C. M. A. Barone, and A. Di Francia. 2020. Hay or silage? How the forage preservation method changes the volatile compounds and sensory properties of Caciocavallo cheese. J. Dairy Sci. 103:1391-1403. https://doi.org/10.3168/ jds.2019-17155.

Stefanon, B., and G. Procida. 2004. Effects of including silage in the diet on volatile compound profiles in Montasio cheese and their modification during ripening. J. Dairy Res. 71:58-65. https://doi .org/10.1017/s0022029903006563.

Urbach, G. 1990. Effect of feed on flavor in dairy foods. J. Dairy Sci. 73:3639-3650. https://doi.org/10.3168/jds.S0022-0302(90)79067 -4 .

van Dorland, A., M. Kreuzer, H. Leuenberger, and H.-R. Wettstein. 2008. Comparative potential of white and red clover to modify the milk fatty acid profile of cows fed ryegrass-based diets from zerograzing and silage systems. J. Sci. Food Agric. 88:77-85. https:// doi.org/10.1002/jsfa.3024.

Verdier-Metz, I., J. B. Coulon, P. Pradel, C. Viallon, and J. L. Berdagué. 1998. Effect of forage conservation (hay or silage) and cow breed on the coagulation properties of milk and on the characteristics of ripened cheeses. J. Dairy Res. 65:9-21. https://doi.org/10 .1017/S0022029997002616.

Verdier-Metz, I., G. Gagne, S. Bornes, F. Monsallier, P. Veisseire, C. Delbès-Paus, and M. C. Montel. 2012. Cow teat skin, a potential source of diverse microbial populations for cheese production. 
Appl. Environ. Microbiol. 78:326-333. https://doi.org/10.1128/ AEM.06229-11.

Verdier-Metz, I., B. Martin, S. Hulin, A. Ferlay, P. Pradel, and J. B. Coulon. 2002. Combined influence of cow diet and pasteurization of the milk on sensory properties of French PDO Cantal cheese. Congrilait 26th IDF World Dairy Congress (ed. CIDIL).

Verdier-Metz, I., B. Martin, P. Pradel, H. Albouy, S. Hulin, M. C. Montel, and J. B. Coulon. 2005. Effect of grass-silage vs. hay diet on the characteristics for cheese: Interactions with the cheese model. Lait 85:469-480. https://doi.org/10.1051/lait:2005032.

Villeneuve, M. P., Y. Lebeuf, R. Gervais, G. F. Tremblay, J. C. Vuillemard, J. Fortin, and P. Y. Chouinard. 2013. Milk volatile organic compounds and fatty acid profile in cows fed timothy as hay, pasture, or silage. J. Dairy Sci. 96:7181-7194. https://doi.org/10 .3168/jds.2013-6785.

Visentin, G., M. Penasa, P. Gottardo, M. Cassandro, and M. De Marchi. 2016. Predictive ability of mid-infrared spectroscopy for major mineral composition and coagulation traits of bovine milk by using the uninformative variable selection algorithm. J. Dairy Sci. 99:8137-8145. https://doi.org/10.3168/jds.2016-11053.
Yokoyama, M. T., and J. R. Carlson. 1981. Production of skatole and para-cresol by a rumen Lactobacillus sp. Appl. Environ. Microbiol. 41:71-76. https://doi.org/10.1128/AEM.41.1.71-76.1981.

\section{ORCIDS}

E. Manzocchi @ https://orcid.org/0000-0002-6397-8300

B. Martin (1) https://orcid.org/0000-0003-2501-8306

C. Bord (ㄱ https://orcid.org/0000-0003-1063-0551

I. Verdier-Metz @ https://orcid.org/0000-0001-6002-3878

M. Bouchon ํ https://orcid.org/0000-0002-7175-7233

M. De Marchi $\odot$ https://orcid.org/0000-0001-7814-2525

K. Giller (๖) https://orcid.org/0000-0002-1276-4548

M. Kreuzer @ https://orcid.org/0000-0002-9978-1171

J. Berard ๑ https://orcid.org/0000-0002-7222-632X

M. Musci $\odot$ https://orcid.org/0000-0002-3980-3922

M. Coppa @ https://orcid.org/0000-0003-2073-0599 